\title{
Interactions between climate change and human activities during the early to mid-Holocene in the eastern Mediterranean basins
}

\author{
Jean-Francois Berger ${ }^{1}$, Laurent Lespez ${ }^{2}$, Catherine Kuzucuoğlu ${ }^{3}$, Arthur Glais ${ }^{4}$, Fuad Hourani ${ }^{5}$, Adrien Barra ${ }^{6}$, and \\ Jean Guilaine ${ }^{7}$ \\ ${ }^{1}$ Université de Lyon, CNRS, Université Lyon 2-Lumière, UMR 5600 EVS, 69007, France \\ ${ }^{2}$ Université Paris Est Créteil (UPEC), UMR CNRS 8591 LGP, France \\ ${ }^{3}$ Université Paris 1-Panthéon Sorbonne, UMR CNRS 8591 LGP, France \\ ${ }^{4}$ Université Caen-Basse Normandie, UMR CNRS 6554 LETG-Caen, France \\ ${ }^{5}$ University of Jordan, Faculty of Archaeology and Tourism, Amman, Jordan \\ ${ }^{6}$ Université de Lyon, CNRS, Université Lyon 2-Lumière, UMR 5600 EVS, 69007, France \\ ${ }^{7}$ Collége de France, Paris, France
}

Correspondence to: Jean-Francois Berger (jean-francois.berger@univ-lyon2.fr)

Received: 8 January 2016 - Published in Clim. Past Discuss.: 23 February 2016

Accepted: 24 June 2016 - Published: 12 September 2016

\begin{abstract}
This paper focuses on early Holocene rapid climate change (RCC) records in the Mediterranean zone, which are under-represented in continental archives (9.2 to $8.2 \mathrm{ka}$ events) and on their impact on prehistoric societies. This lack of data handicaps the general interpretation of climate impacts on human societies, which flourished in recent years. Key questions remain about the impact of early Holocene cooling events on the Mediterranean climate, ecosystems and human societies. In this paper, we discuss some examples from river and lake systems from the eastern to central Mediterranean area (central Anatolia, Cyprus, northeastern and northwestern Greece) that illustrate some palaeohydrological and erosion variations that modified the sustainability of the first Neolithic populations in this region. Results allow us to present direct land-sea correlations and to reconstruct regional long-term trends as well as millennial- to centennial-scale climatic changes. In this context, we question the socio-economic and geographical adaptation capacities of these societies (mobility, technology, economic practices, social organisation) during the "early Holocene" interval (11.7 to $8.2 \mathrm{ka}$ ), which corresponds partly to the Sapropel 1 deposition in the eastern Mediterranean sea.
\end{abstract}

\section{Introduction}

Expected to have had a large impact on past societies, rapid climate changes (RCCs), which start abruptly within one decade or two at the most (in polar records) and most often concern a period of 150 to 400 years, are often considered one of the main environmental factors causing socioeconomic and cultural changes, migrations, and even collapses (Weiss et al., 1993; Cullen et al., 2000; Staubwasser and Weiss, 2006; Weninger et al., 2006). According to this climatic determinism, a RCC would be much harder (if not impossible) for a human society to adapt to, thus leading to radical societal transformations. In the course of this debate, recent and ongoing research on Neolithic societies points to the necessity to focus simultaneously on (i) the economic, socio-cultural, technological and cognitive transformations of the human group living on site(s); (ii) the sharpening of old and new chronological series within the site(s); (iii) the development of contextual analyses associated with geoarchaeological researches; and (iv) investigating, with a highresolution and multi-proxy approach, the palaeoenvironmental records available in the vicinity of Neolithic sites and their connections with the sites, an approach that is at present poorly utilised. Such an approach and methodology are indeed the most appropriate for reconstructing and interpreting 
the relationships between environmental and societal event records which have accompanied (or not) a rapid climate change and to better estimate adaptability to changing environments. As a matter of fact, a lack of a RCC signature in the climatic and environmental proxies studied in any sediment record may have several meanings: an incorrect assessment of a signal, an insufficient chronological control, a disconnection between the locus studied and neighbouring areas where sedimentary archives would be more favourable for recording a rapid climate change, etc. These are the reasons why it is often suspected that the absence of signature of a RCC event in continental archives is more often due to the low temporal resolution of the available records rather than the absence of the climatic signal on the local scale. This problematic situation is now increasingly addressed by new results focusing on high-resolution analyses and chronologies, as well as on records linking both the archaeological sites and their surrounding geomorphologic/environmental archives. In this paper, the goal is to highlight the variety of occurrences of early Holocene RCC records using (i) interconnected water-related systems (rivers and wetlands) associated with Neolithic sites in contrasting areas of the eastern Mediterranean Basin and (ii) the characteristics of the main morphogenic and hydrosedimentary responses to RCC on the catchment or lacustro-palustrine scales. We present below four recently investigated continental fieldwork areas where new data have been acquired concerning the 9.5 to $7 \mathrm{ka}$ time span. These data are discussed in the context of their proximity to excavated archaeological sites or regional cultural trends on the regional scale (central Anatolia, Cyprus, eastern Macedonia, Corfu). Using different spatial scales, from the site to the region and from the eastern to the central Mediterranean, the hydrogeomorphic and ecological impacts of these early Holocene RCCs are evaluated, along with their potential impacts on the first Neolithic societies.

\section{The state of the art}

During the first half of the Holocene, the eastern Mediterranean regions experienced a climate regime significantly wetter than today, coherently indicated by regional marine and terrestrial isotopes (Bar-Matthews et al., 1997; Roberts et al., 2008; Robinson et al., 2006), the Dead Sea level maximum (Migowski et al., 2006) and the Sapropel 1 formation period in the eastern Mediterranean Sea favoured by freshwater high runoff of tropical monsoonal origin (RossignolStrick, 1999; Rohling et al., 2015). During this period, changes in Mediterranean cyclogenesis would have been potentially influenced by lower sea surface temperature (SST) and evaporation (Brayshaw et al., 2011; Rohling et al., 2015). The general trend toward climate amelioration after the Younger Dryas favoured the development and diffusion of agriculture from nuclear areas in the eastern Mediterranean (Willcox et al., 2009), the Levant (Bar-Yosef and
Belfer-Cohen, 1989) and Anatolia (Özdoğan, 2011; Kuzucuoğlu, 2014). This early Holocene phase was nevertheless interspersed by several pluricentennial wetter/drier climatic pulsations. Compared to today, the climate was then much more sensitive to freshwater forcing than to solar activity (Teller and Livingston, 2002; Fletcher et al., 2013). For example, in the Greenland ice cores, three "rapid events" (RCCs) caused by meltwater pulses are recorded at ca. 10.2, 9.2 and $8.2 \mathrm{ka}$, together with at least 11 other similar events documented for the entire early Holocene (Teller et al., 2002; Fleitmann et al., 2008). In the eastern Mediterranean, extension of the Siberian anticyclone to the eastern Mediterranean (regular influx of cold air masses) also played a major role during the Holocene period. For example, cold air from the Siberian High (SH) extension created a rapid SST cooling (Rohling et al., 2002) (Fig. 1). The multi-centennial variability in the GISP2 terrestrial potassium $(\mathrm{K}+)$, a proxy recording the strength and temporality of the SH (Mayewski et al., 1997), shows a stronger SH during some Holocene cold periods in the eastern Mediterranean, with repetitive impacts on the Anatolian/Aegean areas (Rohling et al., 2002; Weninger et al., 2006, 2014). These latter authors identify a "RCC corridor", which runs from Ukraine, through southeastern Europe, and into the Aegean and large parts of Anatolia and the Levant, as well as onto the islands of Cyprus and Crete. Rogers (1997) linked cyclogenesis in the Mediterranean with positive (strong) SH anomalies, while eastern Mediterranean flood activity shows periodically a positive relationship with an increasing trend in the $\mathrm{K}+$ proxy (Benito et al., 2015).

The potential impact of the $9.2 \mathrm{ka}$ abrupt climatic event on human societies during the Neolithic "revolution" has rarely been explored (Borrell, 2007; Flohr et al., 2016), in any case much less so than the $8.2 \mathrm{ka}$ event. In this debate, the effects of the worldwide " 8.2 " climatic event on the Mesolithic and Neolithic societies have been under discussion for a decade, with interpretations varying from abandonment of sites to collapse, and from large-scale migration to sustainability of occupation and social adaptation (for a complete overview, see Gehlen and Schön, 2005; Staubwasser and Weiss, 2006; Weninger et al., 2006, 2014; Berger and Guilaine, 2009; Flohr et al., 2016). Climatic records show that the $8.2 \mathrm{ka}$ event resulted in some of the most extreme environmental perturbations of the Holocene. For this reason, it has often been a subject in the literature since being first discussed (Alley et al., 1997). Extended over a time span of 100-150 years in GISP2-GRIP polar archives (Thomas et al., 2007), its duration has been found to be longer in numerous marine and continental proxies (Fig. 1). In the eastern Mediterranean and other regions, the RCC interval between 8.6 and $8.0 \mathrm{ka}$ spans a longer time period than in the ice record, supporting the idea of an enhanced Siberian highpressure anticyclone over Asia (Rohling and Pälike, 2005; Weninger et al., 2014) controlling a global intensification of atmospheric circulation with cooler temperatures in polar regions (Mayewski et al., 2004) and drier and cooler condi- 


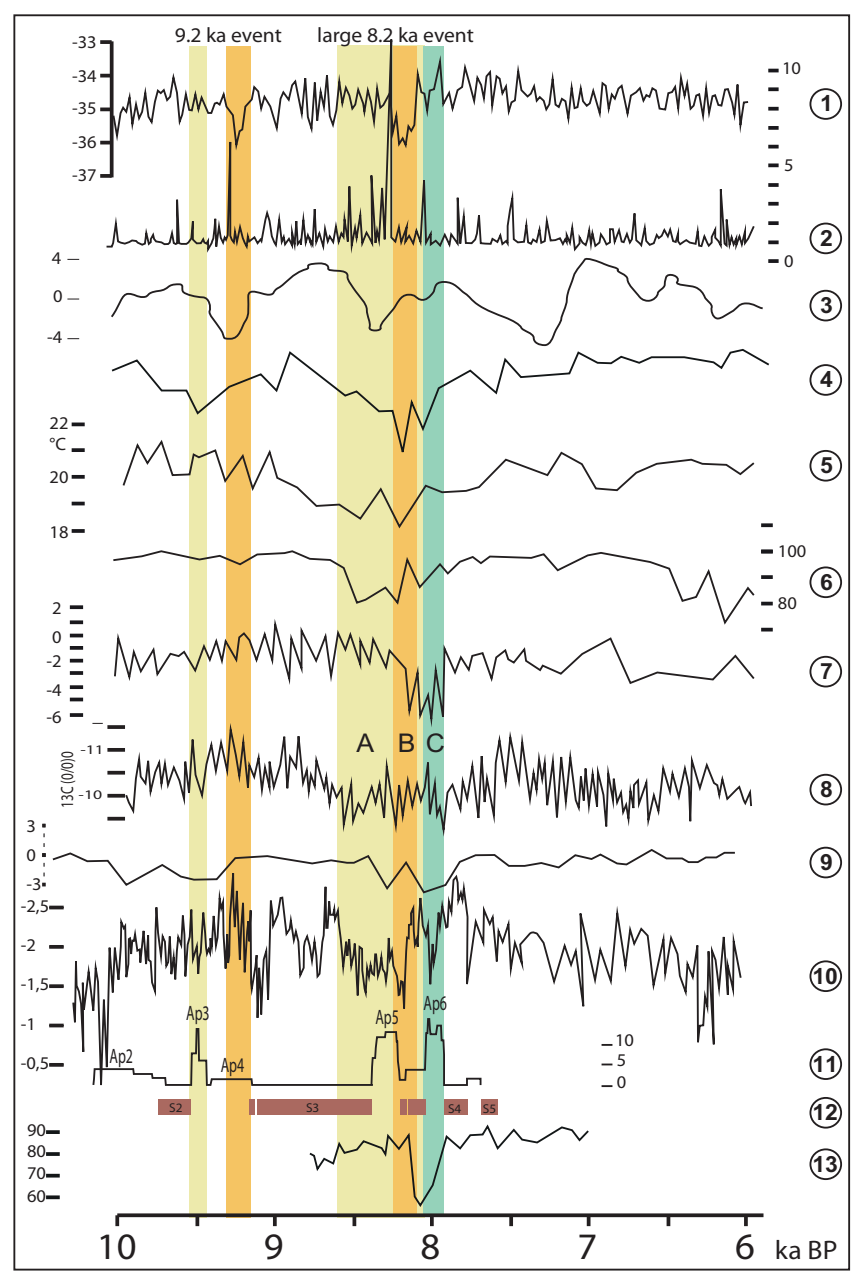

Figure 1. Northern Hemisphere palaeoclimate/pedosedimentary records illustrating Holocene rapid climate changes (RCCs): 1, Greenland GRIP ice-core $\delta^{18} \mathrm{O}$ (Grootes et al., 1993); 2, highresolution GISP2 non-sea-salt (nss) $[\mathrm{K}+]$ as a proxy for the Siberian High (Mayewski et al., 1997); 3, ice-rafted debris in North Atlantic (Bond et al., 2001); 4, eastern Aegean SL21 (sea surface temperature, SST) fauna (Marino et al., 2009); 5, MD952043 SST; 6, (C) eastern Mediterranean core LC21 (SST) fauna (Rohling et al., 2002); 7, Steregiou (Romania) pollen-based temperature of peat pollen (Feurdean et al., 2008); 8, Sofular Cave $\delta^{13} \mathrm{C}$ (northern Turkey; Fleitmann et al., 2009 ); 9, Lake Maliq pollen-based temperature of the coldest month (Bordon et al., 2009); 10, Qunf Cave (Q5), ${ }^{18} \mathrm{O}$ (\%0 VPDB) (Fleitmann et al., 2003); 11, Sidari valleys 1 and 2 (Corfu), gully erosion/fluvio-colluvial aggradation (CPDF, this study); 12, Sidari valleys 1 and 2, soil formation phases (Corfu) (this study); 13, Tenaghi Philippon northern Greece tree pollen (\%) (Pross et al., 2009). Yellow vertical bars underline the 9.2 and $8.2 \mathrm{ka}$ event phases. The yellow, orange and green bars (letters A, B, and $\mathrm{C}$, respectively) represent a possible tripartite temporal structure of the 8.2 ka event (discussed in the text).

tions in the Mediterranean Basin (Rohling et al., 2002; BarMatthews et al., 2003; Fletcher and Zielhofer, 2013; GómezPaccard et al., 2016). At the same time, pollen and SST data have been increasingly studied in marine Mediterranean archives in the last 15 years.

In parallel to these ice and marine records, Mediterranean Basin scaled continental records reveal a paucity of evidence of early Holocene RCC. For example, Berger (2015) and Berger et al. (2016) underline episodes of lateral mobility/erosion of rivers and successive entrenchments of active beds, although the period is dominated by a multimillennium-long predominance of pedogenic processes. Although early Holocene earth-surface processes are rarely documented in clear geomorphological and chronological frameworks from the southern Levant, there is some evidence for abrupt geomorphological responses in the most fragile (semi-arid) regions during Holocene RCCs (Cohen-Seffera et al., 2005). But there is a general lack of very precise geomorphological studies for this period (Berger and Guilaine, 2009; Zielhoffer et al., 2008, 2012).

Divergent information from different proxy records as well as chronological uncertainties is often a major limitation to our understanding of abrupt climatic changes and their impact on the continental environment (Desprat et al., 2013). Early Holocene palaeoenvironmental data derive first from inferred changes in lake hydrology (isotopes and salinity changes, water level variations; Magny, 2004; Eastwood et al., 2007; Roberts et al., 2008, 2011; Kuzucuoğlu et al., 2011), quantitative pollen studies (Eastwood et al., 1999; Roberts et al., 2001; Pross et al., 2009; Peyron et al., 2011; Bordon et al., 2009), fire analysis (Vanniere et al., 2011), and cave speleothems records (Bar-Matthews et al., 1997; Frisia et al., 2006; Verheyden et al., 2008; Göktürk et al., 2011) and marine cores (e.g. Kothoff et al., 2008; CombourieuNebout et al., 2013; Desprat et al., 2013; Fletcher et al., 2013) (Fig. 2). Multi-proxy comparisons (pollen-inferred changes in plant functional types vs. modern analogues) help in identifying a strong connectivity with the Mediterranean watersheds, in particular when deciduous woodland switches to sclerophyllous woodland and scrub, or when mountainous assemblages increase during colder events (Peyron et al., 2011; Combourieu-Nebout et al., 2013).

Despite these many recent palaeoclimate studies, it is still difficult to imagine the relationships between climate and hydrogeomorphology in the eastern part of the Mediterranean Basin at the centennial scale during the early Holocene. For example, is it possible to consider a synchronous and similar hydroclimatic and geomorphic functioning all through the area from the Ionian-Aegean Basin to the Levant regions? Is there a latitudinal climatic barrier between a northern and southern part of the eastern Mediterranean, as there is between the central and western Mediterranean (Magny et al., 2013)? How much seasonal or annual water is available for soil and vegetation, notably during the main RCCs? What links can be found between changes in practices or in population movements that may be connected to past hydrological changes in the continental areas? 
Several archaeology-related studies are now dedicated to the production of specific data on societal vulnerability during the early Holocene (e.g. Clare and Weninger, 2008; Bocquet-Appel et al., 2014; Borrell et al., 2015; Flohr et al., 2016, "2010-2020" Paléomex project). These projects cover the widest possible field of alternative societal modes and types of responses to environmental changes versus natural hazards. The RCCs' mechanism and their millennial cycles during the Holocene give opportunities to study the impact of rapid events on cultural transitions and/or migrations/mobility and to explore the societal adaptability modes in stress conditions through time and in specific contexts. The current main hypotheses are based, on the one hand, on regional chronocultural patterns defined by cumulative probability density function (CPDF) techniques and, on the other hand, on the time parallelism between a decrease in radiocarbon date clusters and the assertion of a RCC. As proposed by Flohr et al. (2016), a more critical approach is now clearly needed to better characterise socio-environmental relations with climate and environmental changes during RCC, an approach that would be more trustable than the use of regional ${ }^{14} \mathrm{C}$-dated series, which may be neither rigorously qualitychecked nor solidly correlated in space and time. In order to face the need for highly constrained dating strategies in archaeological contexts, the intra-site scale is now being applied to sites such as Çatalhöyük (Clare and Weninger, 2008; Marciniak et al., 2015), Aşıklı Höyük (Stiner et al., 2014) and Tell Sabi Abyad in the upper Euphrates (van der Plicht et al., 2011; Akkermans et al., 2014). Extensively applied in stratigraphy as well as in space at the site, this approach aims to establish continuity/discontinuity in occupation and cultural changes within a sensitive timing. For example, Clare and Weninger (2008) and van der Plicht et al. (2011) demonstrated that a multiplication of ${ }^{14} \mathrm{C}$ dates by CPDF at a single site can fill or confirm the suspicion of a hiatus. A critical analysis of the state of regional radiocarbon databases is therefore essential, not only, as recently applied by Flohr et al. (2016), with a selection of radiocarbon dates but also by a systematised intra-site stratigraphic and taphonomic evaluation such as that recently conducted on the Dikili Tash and Sidari sites (Greece) (Lespez et al., 2013, 2016; Berger et al., 2014). We consider that this approach is the most reliable way to observe the degree of continuity of human occupation and thus to establish its possible links to local hydrogeomorphological dynamics during RCCs. However, such archives are rare and primarily dependant on the site position in the catchment area, on the proximity of the site with favourable sedimentary archive areas (e.g. floodplains, swamps, foot slopes) and on the type of site (tells being less favourable to hydrosedimentary records as soon as they emerge from the floodplains). In addition to a lack of ${ }^{14} \mathrm{C}$ dates on site, the lack of archaeological data matching the same timing as sudden and short-lived events may have other causes than the absence of a link: a prevailing theoretical bias, old wood effects (dates performed on charcoal are usually used, although short-lived organic matter should be preferred in the case of rapid events), and restricted excavation of site surfaces and periods.

Not only do many palaeoclimate and environmental records have neither sufficient temporal resolution nor chronological precision but also the sensitivity of a continental record to detect a decadal-scaled climatic anomaly is rarely assessed. For this latter factor, more detailed geographical and bioclimatic local frameworks within regional assessments are needed. The availability of such assessments is necessary for discussing not only the local impacts of climate events on the resources and landscapes (Clare and Weninger, 2010) but also the societal impact or non-impact of a RCC (Roberts et al., 2011; Kuzucuoğlu, 2015) and our knowledge of past adaptation strategies (Berger, 2006; Berger and Guilaine, 2009; Lespez et al., 2014, 2016; Flohr et al., 2016). As far as the study of early farming societies is concerned, data about micro-regional and local effects of RCCs will usefully replace or complete the information delivered by the key regional - and remote - climate references which are regularly called for in research papers: glacial, marine, continental dendrochronological series, speleothems, etc. (Weninger et al., 2006, 2009; Kuzucuoğlu, 2009). Local detection of RCC impacts are still too rarely attested to on archaeological sites or in continental river archives close to sites occupied by the first farmers or the last hunter-gatherers (Berger and Guilaine, 2009; Zielhoffer et al., 2012; Lespez et al., 2013; Berger et al., 2016). Prehistorians have discussed the impact of the $8.2 \mathrm{ka}$ event in the Balkans, but their discussions still lack solid socio-environmental field documentation and interpretation, and implications remain too often theoretical (Bonsall, 2007; Budja, 2007; Nikolova, 2007). We thus propose here a "bottom-up approach" of the impact of climate changes on the early Neolithic societies. We intend to demonstrate that precise geoarchaeological investigations in Neolithic sites, when based on systematic stratigraphy studies, rigorous radiocarbon series and on a contextual archaeological approach, end up proposing new socio-environmental schemes on the local scale. At the same time, we explore new hypotheses about the impacts of the early Holocene RCCs on the environments as well as the responses of Neolithic societies.

\section{Material and methods: new continental data with high chronological resolution in the centre and east of the Mediterranean Basin}

\subsection{Central Anatolian and Cyprus cultural contexts}

The wide and endorheic plains of central Anatolia (Figs. 2 and 3) open in steppic plateaus ca. 1200-1300 m altitude. The altitudes of the three main plains are ca. $920 \mathrm{~m}$ a.s.l. (Tuz Gölü, to the north), 1000 ma.s.l. (Konya and Ereğli, to the south), and $1050 \mathrm{~m}$ a.s.l. (Bor, to the east). In these plains, the current climate is semi-arid with mean annual precip- 
itation ranging from 280 to $340 \mathrm{~mm} \mathrm{yr}^{-1}$ (Konya and Tuz Gölü Plain, respectively, southern Cappadocian lowlands). This semi-aridity contrasts with the fact that, from ca. $10.5 \mathrm{ka}$ on, the most ancient Neolithic sites of Anatolia East of the Taurus Mountains are founded in the Cappadocian highlands (Özbaşaran, 2011) and in the Konya Plain (Baird, 2012; Özdoğan et al., 2012), in a time frame similar to that of the PPN (Pre-Pottery Neolithic) on the other side of the Taurus Mountains (southeastern Anatolia: Özdoğan, 2011). Indeed, after the Epipalaeolithic (Pınarbaşı-Karaman: 11.2-9.8 ka), two PPN (excavated) sites develop in central Anatolia, starting shortly after the Holocene onset and lasting until $9.4 \mathrm{ka}$ : Aş1 klı (10.5-9.4 ka, in Cappadocia) and Boncuklu (10.4$9.4 \mathrm{ka}$, in the Konya Plain). Before and after the demise of these sites, three pre-PN sites appear: Musular in Cappadocia $(9.6-9.0 \mathrm{ka})$, which is inhabited only a few centuries, while the occupation of the two other sites continues during the 9th millennium BP (Can Hasan III: 9.6-8.6 ka) and the 8th millennium BP (Çatalhöyük East and West: 9.5-7.5 ka; Weninger et al., 2014; Marciliak et al., 2015).

Other cultural changes occur in both regions during the 8.6-8.0 ka time span. In Cappadocia two sites overlap the 8.2 ka event (Tepecik: 9-7.5 ka; Kösk: 8.5-7.5 ka). In the Konya plain, two sites follow one another ca. $8.0 \mathrm{ka}$ : Pınarbaş1-Karaman (8.5-8.0 ka) and the second phase at Can Hasan (8.0-7.6 ka). In spite of the small number of excavated sites in both Cappadocia and the Konya Plain, this list does not show any clear cultural "rupture" at either ca. $9.2 \mathrm{ka}$ or ca. $8.2 \mathrm{ka}$. However, a change may have happened at ca. $9.4 \mathrm{ka}$ at the end of the Pre-Pottery Neolithic B (PPNB) which possibly ended with a PPNA phase at Musular (?). Clearly, 8.6, 8.0 and especially $7.6 \mathrm{ka}$ seem to be pivotal dates:

- 8.6 ka marks the end of the first occupation phase of Can Hasan III and the start of that of Köşk and Pınarbaşı; however, Tepecik and Çatalhöyük are continuously occupied.

- 8.0 ka marks the end of Pınarbaşıand the start of the Can Hasan second phase.

- $7.5 \mathrm{ka}$ marks the end of occupation of Çatalhöyük (West), Köşk, Tepecik, and the Can Hasan second phase.

Central Anatolia neighbours the nuclear areas of the PPNA $(11.7-10.5 \mathrm{ka})$ in the Levant and of southeastern Turkey (middle and upper Tigris and Euphrates valleys). Where identified (in the Levant, southeastern Turkey, Iran, Cyprus, central Anatolia), the PPN corresponds to a "Neolithisation" period during which packages composed of several or all characteristics of the Neolithic are identified in excavated settlements: sedentism, housing, pre-domestication (followed possibly by domestication) of sets of plants and/or animals (Fuller et al., 2011; Zeder 2011; Stiner et al., 2014), symbolism, art, social organisation and ritual behaviour (Cauvin,
2002; Simmons, 2011). Increased sedentism and plant and animal domestication practices are asserted during the period of relative climate stability that follows rapidly the turmoil of the Holocene onset warming up and its consequences on the vegetation and water resources. This has greatly contributed to conceiving the Neolithisation processes in the eastern Mediterranean as an incremental continuum (including several and distinct successful and unsuccessful attempts: Willcox et al., 2012) in disconnected "cores" spread over the region, with relatively minor disruptions (Borrell et al., 2015). Recently, a major cultural discontinuity has been observed in the archaeological PPN records of the northern Levant which lasted from 10.2 to $9.8 \mathrm{ka}$ and was followed by a substantial cultural transformation indicating a break in the Neolithisation process (Weninger et al., 2009; Borrell et al., 2015). This early discontinuity corresponds to a hiatus in settlements, which covers almost the entirety of the time span traditionally attributed to the early PPNB in the Levant (10.2-9.6 ka) (Borrell et al., 2015).

In central Anatolia, after the abandonment ca. $9.5 \mathrm{ka}$ of early PPNB sites in the Konya Plain (Boncuklu, Can Hasan III) and Cappadocia (Aşıklı), younger PPNB sites appear at other locations: ca. 9.6/9.5 ka in Cappadocia (Musular site), and 9.4/9.3 ka in the Konya Plain (Çatalhöyük East). Musular, a site specialising in butchery, is abandoned ca. $9.0 \mathrm{ka}$ before the appearance of pottery. From the west of the Konya Plain to the Lake District, where sites are founded ca. $9.2 \mathrm{ka}$ without pottery (PPN) as in Bademağacı, and to the Aegean region of Anatolia (Ulucak), Neolithic occupation continues with no hiatus into and throughout the early Neolithic period, which starts quickly, ca. 9.0/8.9 ka, with the appearance of pottery. Pottery also appears within a similar time frame in many other sites in Cappadocia (e.g. Tepecik-Çiftlik; Köşk Höyük) as well as the Mediterranean (e.g. Yumuktepe) and the Aegean (e.g. Yeşilova, Ulucak etc.) (Fig. 2, with references therein, especially in Özdoğan et al., 2012a, b). New results (e.g. Özdoğan et al., 2012a, b; Stiner et al., 2015) and those from ongoing syntheses (e.g. Özdoğan, 2011; Kuzucuoğlu, 2014) suggest that long-distance Neolithisation dynamics originated out of a core located in the Konya Plain and Cappadocia. This diffusion arrived in the Aegean region ca. 9.1-9.0 ka (Özdoğan 2011). In the eastern Mediterranean as well as in central Anatolia, Flohr et al. (2016) show that ${ }^{14} \mathrm{C}$-date-based spatio-temporal reconstructions of sites distributions do not provide evidence for widespread migrations ca. 9.2/9.0 ka. As a matter of fact, in Anatolia the apparent westward-progressing cultural influences do not automatically mean "departure" or "migration" from the large plains ca. 9.2/9.0 ka but rather "diffusion" (Kuzucuoğlu, 2014). For example, the typical highly populated and densely built large PPN "villages" of Cappadocia (Aşıklı) and Konya Plain (Çatalhöyük East) do not exist anywhere else, nor do they afterwards. In addition, the earliest Pottery Neolithic layers (continuing PPN) in the Lake District are culturally distinct from the contemporaneous ones in the Konya Plain located 


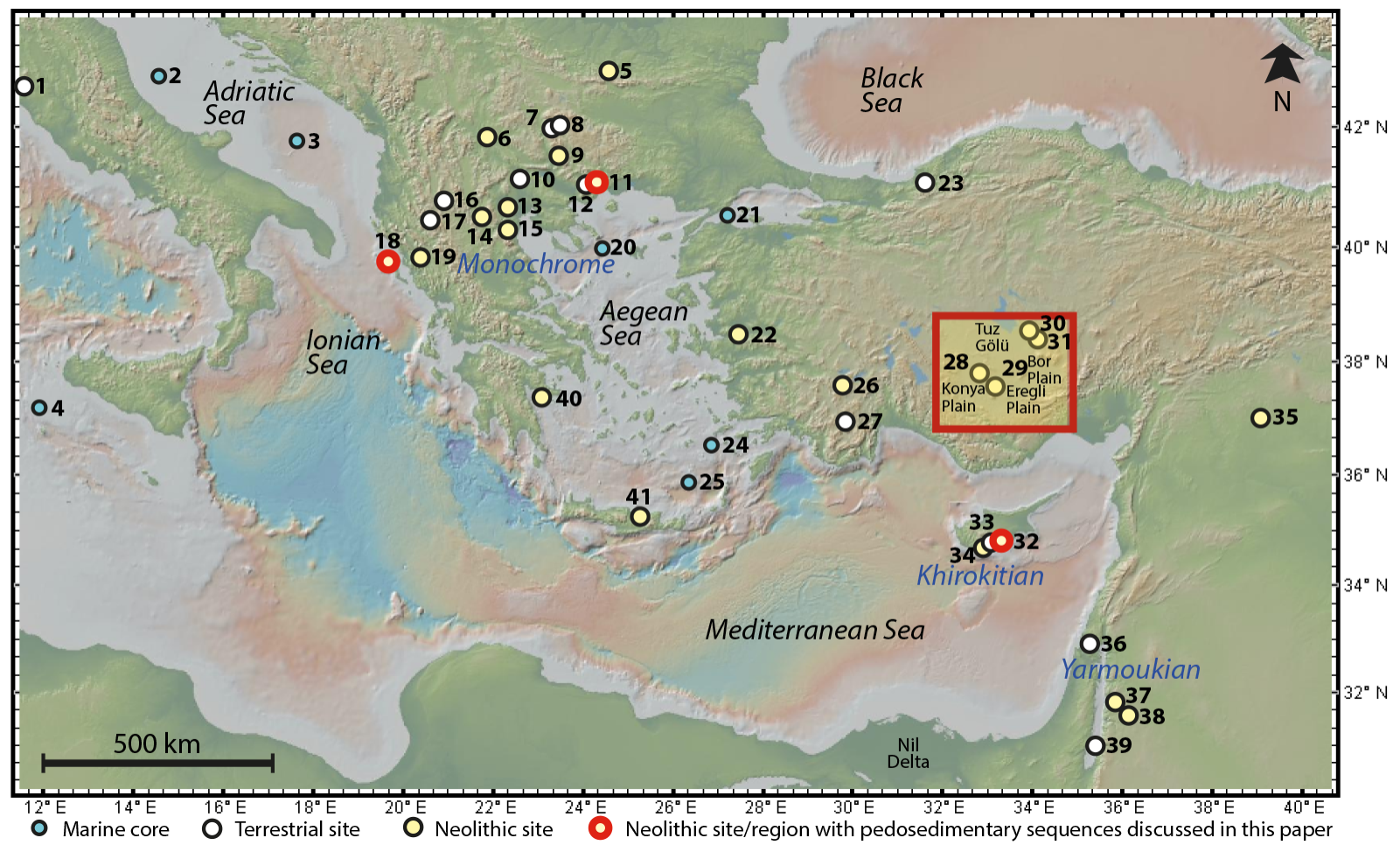

Figure 2. Map of main sites cited in the text: 1, Lake Accesa; 2, CM-92-43; 3, MD90-917; 4, MD 04-2797; 5, D $\int$ uljunica; 6, Anzabegovo; 7, Lake Trilistnika; 8, Lake Ribno; 9, Kovacevo; 10, Lake Dojran; 11, Dikili Tash; 12, Tenaghi Philippon marsh; 13, Nea Nikomedia; 14, Mavropigi-Filotsairi; 15, Paliambela; 16, Lake Prespa; 17, Lake Maliq; 18, Sidari 1/2; 19, Konispol Cave; 20, SL-152; 21, KL-71; 22, Ulucak; 23, Sofular Cave; 24, NS-14; 25, LC-21; 26, Hacilar; 27, Lake Golishar; 28, Çatalhöyük; 29, Can Hasan; 30, Musular; 31, Aş1klı; 32, Khirokitia-Maroni River; 33, Vasilikos Valley; 34, Shillourokambos; 35, Tell Sabi Abyad; 36, Soreq Cave; 37, Wadi Shu'eib; 38, Ain Ghazal; 39, Dead Sea; 40, Franchthi Cave; 41, Knossos. Main Neolithic cultures of the 9th millennium cal BP are in blue.

to the east (Duru, in Özdoğan et al., 2012b). Even with late PPN/early PN starting early in the Konya Plain and Cappadocia, archaeological records do not evidence any cultural connection between these two regions and the early Neolithic in the Lake District (Fig. 2). In addition, in western Anatolia, early Neolithic cultural material from sites occupied at the beginning of the 9th millennium records the mixing of local traditions with other cultures from the eastern Mediterranean (diffused along the sea shores?) as well as from the Lake District (diffused westward?) with, again, no influence from the "core area" in central Anatolia (Konya Plain, Cappadocia). Consequently, any approach which aims to understand the relationships between climate and human societies during the time of the Neolithic development and expansion in Anatolia (Kuzucuoğlu, 2014) must take into account the regional dimension of the economic, technological and social characteristics of the Anatolian Neolithic, especially in the plains and plateaus of central Anatolia (Özbaşaran, 2011).

In Cyprus, a cultural change is initiated ca. 9.6/9.5 ka (emergence of the Khirokitia culture: Le Brun et al., 2009). At the Shillourokambos site (Fig. 2), the change occurs in the early $\mathrm{C}$ phase, initiating a different cultural package which lasted the second half of the 10th millennium cal BP. The cultural change is visible in the quick decline of the exquisite lamellar tools obtained in the previous phase by bipolar knapping (a strong PPNB marker in the Levant), replaced by production that is directed towards robust pieces (thick and irregular blades, pikes, and sickles with parallel hafting to the edges) (Briois, 2011). At the same time, there is a decrease in grinding instruments around $9.2 \mathrm{ka}$, after an agricultural development had lasted during the previous three centuries (Perrin, 2003). Imports of Cappadocian obsidian collapse, and Cyprus no longer has any contact with Anatolia and the eastern Mediterranean. The habitat reduces in size, concentrating in the southern part of the site. Building materials evolve with the abandonment of the proto-brick for mud-building techniques. From $9.2 \mathrm{ka}$ on, sheep husbandry plays an important part, perhaps in association with the development of pastoralism (Vigne et al., 2011). These cultural and economic changes have never been faced with climato-environmental evolutions, in spite of their quasisynchronicity with a first global signal (Fig. 1). Discussions about the relationships between cultural changes identified in the Cypriot PPNB sites and the $9.2 \mathrm{ka}$ event are not yet possible because there is still no clear temporal synchronisation between the two sets of data. Nevertheless, the question 


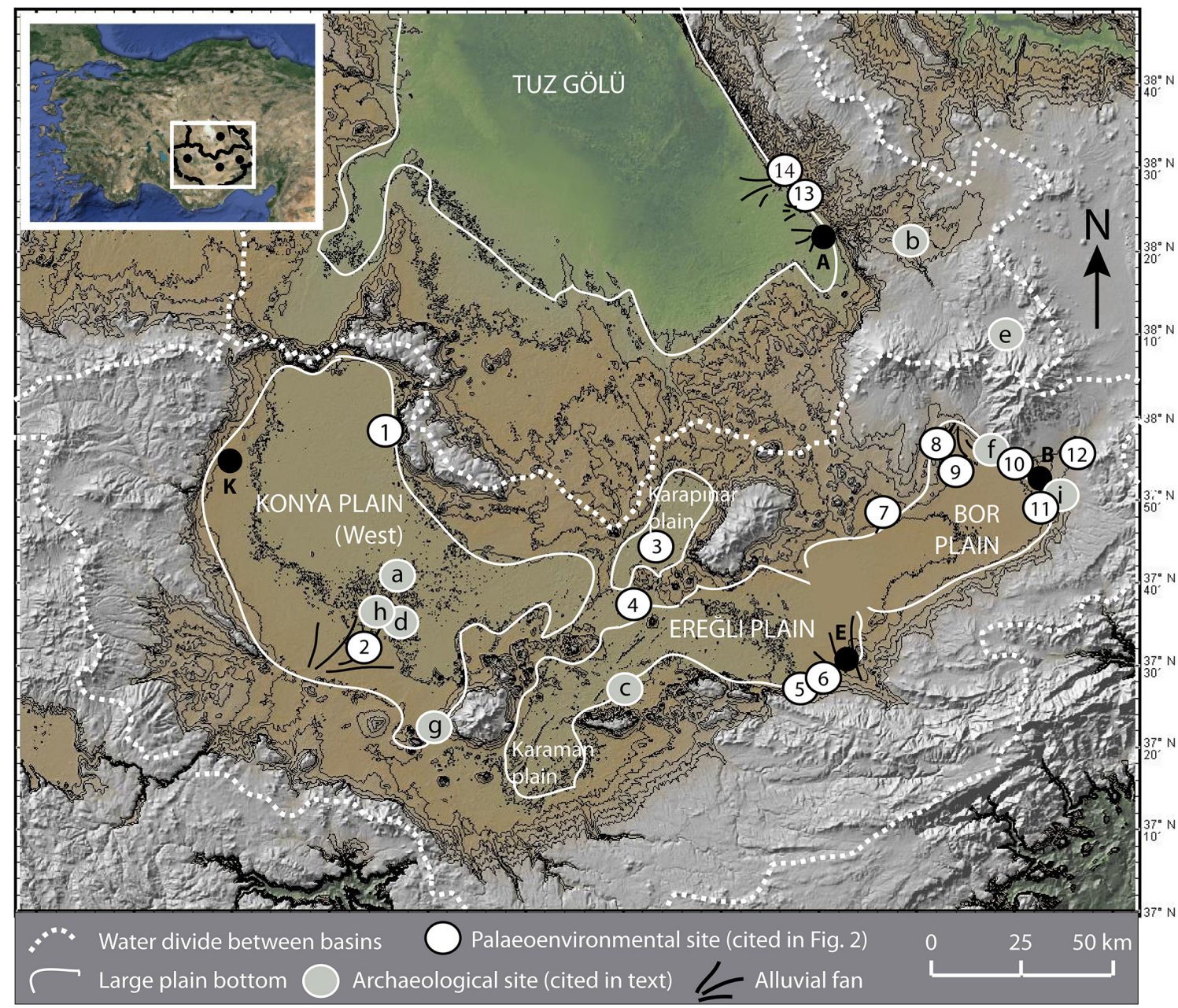

Figure 3. The main large plains of endorheic central Anatolia and location of sites cited in the text and in Fig. 7. Main cities: K, Konya; E, Ereğli; B, Bor; A, Aksaray. Palaeoenvironmental sites: 1, Yarma (Kuzucuoğlu et al., 1999); 2, Çarsamba fan (Boyer et al., 2006); 3, Sultaniye (Kuzucuoğlu et al., 1997); 4, Karapı nar sand dunes (Kuzucuoğlu et al., 1998); 5, Düden (Fontugne et al., 1999; Kuzucuoğlu et al., 1999); 6, Adabağ (Bottema and Woldring, 1984); 7, Zengen; 8, Bayat; 9, Kayı; 10, Pınarbaş1; 11, Bahçeli; 12, Sazlıca; 13, MelendizÇiftlik (Kuzucuoğlu et al., 1993); 14, Alluvial fans (Naruse et al., 1997; Kashima et al., 2002). Sources for 7 to 12 : Kuzucuoğlu et al., 2016. Excavated Neolithic sites cited in text: a, Boncuklu; b, Aşıklı; c, Can Hasan III; d, Çatalhöyük East; e, Tepecik-Çiftlik; f, Pınarbaş1-Karadağ; g, Pınarbaş1-Bor; h, Köşk Höyük; i, Çatalhöyük West.

of climate control is raised in Cyprus during the economic transition toward pastoralism during this period (Vignes et al., 2011). Such an assumption, for example, has been recently proposed for the eastern Mediterranean by Flohr et al. (2016). We use the Khirokitia site, a Cypriot late PPN village dated to 8.6-7.5 ka (Le Brun et al., 1987; Le Brun and Daune-Le Brun, 2009), to improve the discussion on RCC impact and human occupation on the island. This site is located on the southern foothills of the Troodos Mountains, at about $6 \mathrm{~km}$ from the Mediterranean shoreline (Fig. 4a). It occupies the flanks of a limestone rocky mound (around $216 \mathrm{~m}$ above sea level), bounded to the north and east by the Maroni River bed (Fig. 4b). At the present time the river channel is ephemeral and forms a rather deep and narrow valley cut down through a terrace series of Quaternary conglomerates and older fluvio-marine deposits. The stratigraphic sequence of the site comprises two major series of occupational levels. The articulation between both levels is dated to nearly the end of the seventh millennium BC (around $8.2 \mathrm{ka}$ ). This transition period is marked by a spatial redistribution within the village where an areal shift and a habitat contraction occur, while a change in the botanical and zoological records is noticeable (Le Brun and Daune-Le Brun, 2010; Le Brun et al., 2016). Detailed geoarchaeological investigations have been performed, mainly at the foot of the eastern slope of the site, where the archaeological remains meet the river, and on the surrounding river deposits (Hourani, 2008) (Fig. 5). 


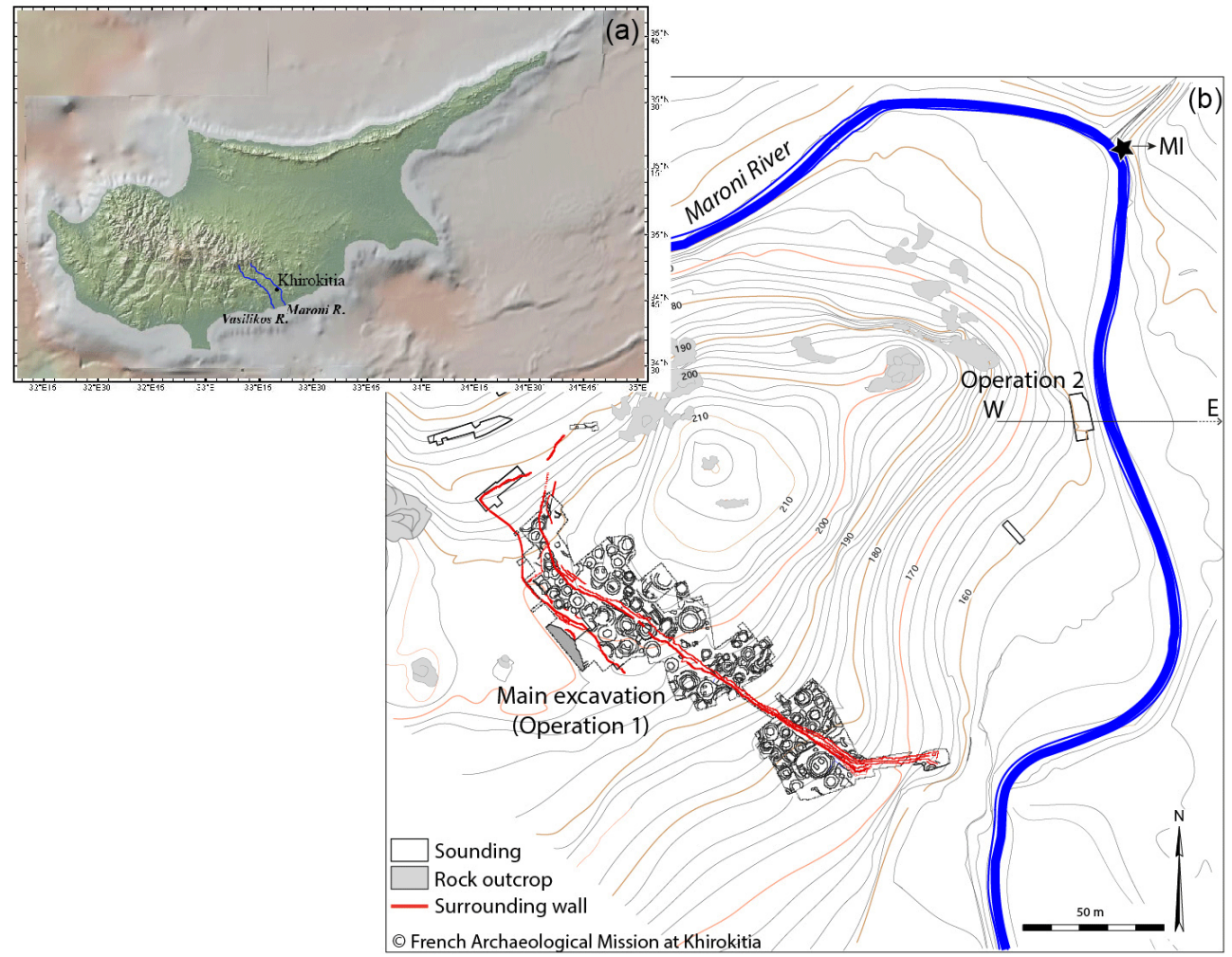

Figure 4. (a) General location of the Pre-Pottery Neolithic site of Khirokitia and of Vasilikos Valley, mentioned in the text. (b) Topographical map of Khirokitia illustrating the position of the site in relation to the Maroni River and the location of the different studied areas.

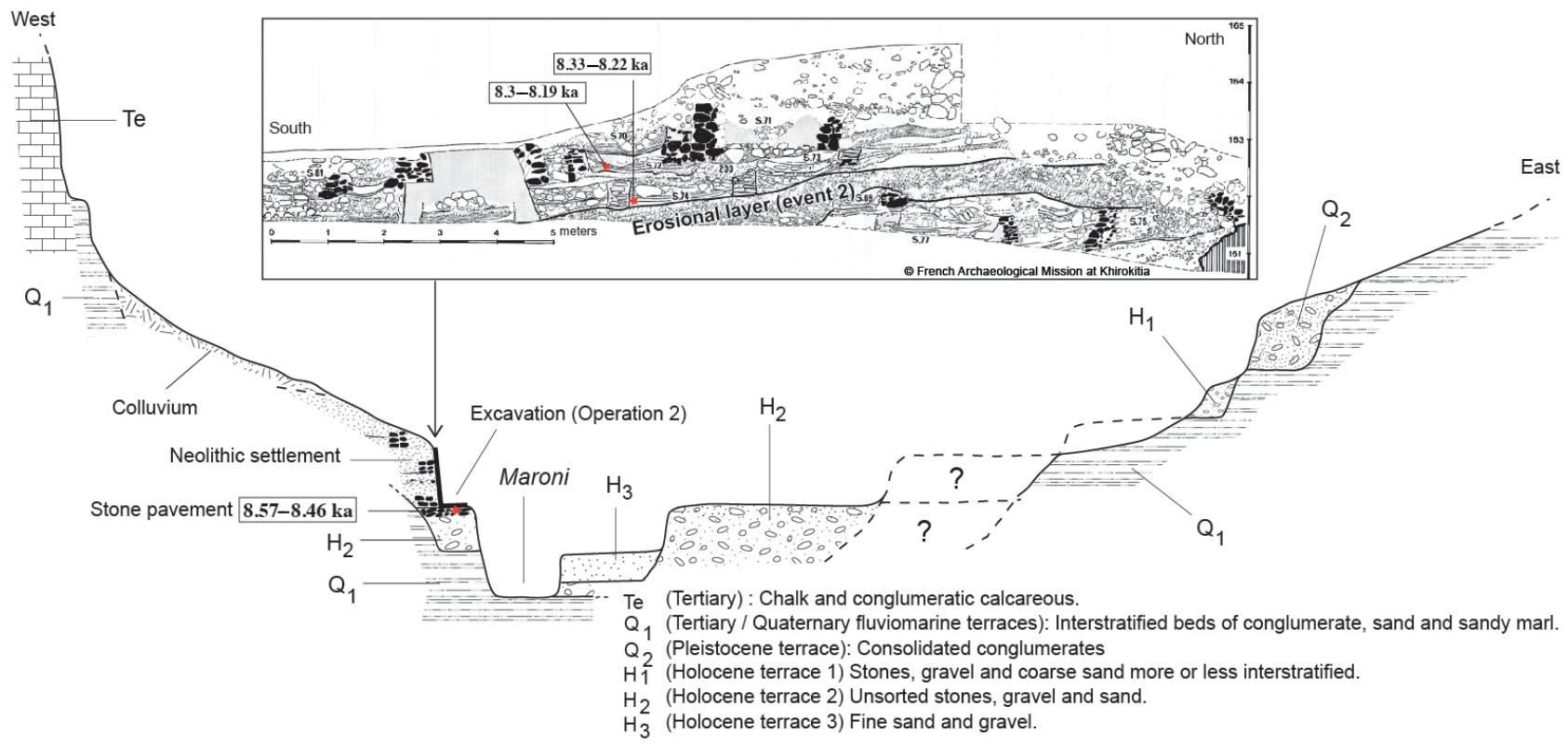

Figure 5. (a) Synthetic cross section of the Maroni Valley at the foot of the eastern slope of the site showing the depositional environments of the river and the situation of the studied archaeological sequence. The location of the section is shown in (b), which is a north-south section through the occupation levels at the river border (operation 2) with the stratigraphic position of the second major erosional event. 


\subsection{Northern Greece: cultural and archaeological contexts}

The tell of Dikili Tash is located in the southeastern part of the Drama Plain, in eastern Macedonia, northern Greece (Fig. 2). It is one of the largest tells in northern Greece, covering an area of ca. $4.5 \mathrm{ha}$, with its highest point standing at ca. $15 \mathrm{~m}$ above current ground surface. A freshwater spring lies immediately to the northeast of the tell, and it opens on a large swamp to the south (Tenaghi Philippon) about which many environmental studies have been published (Fig. 6). Ongoing excavations have provided a good insight into the long stratigraphic sequence of this settlement from the bottom of the plain, completed by coring surveys in the deeper humid zones at the southern periphery of the site (Lespez et al., 2013, 2016; Glais et al., 2016). The deepest archaeological level, very close to the natural soil (a brown leached soil), has been dated to $8.54-8.38 \mathrm{ka}$, i.e. early Neolithic.

The prehistoric site of Sidari, located in a small coastal valley dug in marine Pliocene detrital formations in northwestern Corfu (Figs. 2 and 7a), is a crucial milestone to explain the modalities of the Neolithisation phase in the Adriatic zone. It represents the oldest Neolithic site known in the central Mediterranean (8.3 ka) (Sordinas, 2003; Berger et al., 2014). Deep in the fill of a small valley, the archaeological excavation revealed an early Neolithic phase with red monochrome ceramics, domestic fauna, cereals and mud houses, whose economic status will be specified by the ongoing monographic publication of the French-Greek team (Fig. 7c). Together with Odmut (Bosnia and Herzegovina) and Konispol Cave (Albania) (Sordinas, 2003; Kozlowski et al., 2004; Forenbaher Miracle, 2005), Sidari was originally considered one of three sole sites in northwestern Greece and the southern Adriatic area with an apparent Mesolithic-early Neolithic stratigraphic continuity. On the basis of our new contextual geoarchaeological study (Berger et al., 2014), we recently discussed this aspect, refuting the original interpretation made by Sordinas $(1966,1973)$. This coastal sector is part of a vast Tertiary sedimentary basin presenting a hilly morphology that displays vast and thick Holocene alluvial formations. Today, rainfall is extremely significant, with an average of $1000 \mathrm{~mm} \mathrm{yr}^{-1}$; it is thus the most humid region in Eurasia at this latitude $\left(39^{\circ} \mathrm{N}\right)$. This humidity is mainly related to the orographic impact of the Balkan mountain barrier along the east of the Adriatic zone. Two valleys have been studied (Sidari 1 and 2). These are tributaries of the small coastal Peroulades River (Fig. 7a), which provides its occupants with sustainable water resources, a rich wetland habitat and deep alluvial soils. The geoarchaeological study compares the two low-rank watersheds (close to $400 \mathrm{~m}$ a.s.l.). In both the open, stratified, archaeological site (Sidari 1) and in its neighbouring small valley (Sidari 2), a similar sedimentary sequence shows a thick sequence $(5$ to $7 \mathrm{~m})$. The study of these sequence evidences a succession of Holocene palaeosols and a highly favourable hydromorphological con- text (interlocking channels). Sidari 1 is associated with a dense archaeological occupation and Sidari 2 with a much less anthropised and deeper archive (Fig. 7c, d).

In between these two sites, we also need to insert the recent discovery of the Mavropigi-Filotsairi site on the Kitrini Limni riverbank in western Macedonia (KaramitrouMentessidi et al., 2013). The radiocarbon chronology of this site is based on 17 dates of seeds, bones and charcoal and confirms the establishment of a monochrome Neolithic around $8.5 \mathrm{ka}$ (Fig. 12).

\subsection{Field and laboratory methods, chronostratigraphic buildings}

Intra-site soil and geomorphological studies performed in Sidari, Dikili Tash and Khirokitia allow for discussing the settling of these pioneer Neolithic dwellings in active sedimentary areas (valley floors, small thalwegs). Such a location gives the opportunity to identify and measure impacts of sedimentary and hydrogeomorphological processes. Our research is based on a classical field approach, mainly contextual, which uses in situ cultural horizons and series of stratified radiocarbon dates to build local chronostratigraphic patterns and to discuss the syn- and post-depositional impacts. The multi-proxy analyses (grain size distribution, geochemistry, geophysics, micromorphology) that are still in progress are not discussed in detail in this paper, which focuses primarily on chronostratigraphic contexts. In Sidari, a CPDF analysis is used to better specify and compare the chronology of hydrosedimentary and pedological activity in the two sites. A local database integrating Sidari 1 and 2 sites has been compiled. It integrates 33 radiocarbon dates from three main geomorphological contexts: channel fills, floodplain overbank deposits, and palaeosol. ${ }^{14} \mathrm{C}$ dates have been performed using guidelines set out by Johnstone et al. (2006). BP calendar ages, including $1 \mathrm{~s}$ error range, were summed using a Microsoft Excel macro.

Regarding the site of Dikili Tash, geomorphological studies have focused on the tell and its surroundings (Lespez et al., 2013, 2016) (Fig. 6). The proximity of a swamp (Tenaghi Philippon) gave us the opportunity to follow a strategy of complementary palaeoenvironmental analyses, centred on the study of pollen, non-pollen palynomorphs (NPPs) and fire signal in order to reconstruct the history of the local and regional vegetation and of fires. At the same time, these proxies also allowed the dating of the emergence of agropastoral practices and the temporal fluctuations of the human influence on the environment. Pollen and NPP analyses have been performed on sediments from core Dik12 retrieved from the site bottom, as well as from Dik4, which was located $2 \mathrm{~km}$ southwest of the site, on the edge of the Tenaghi Philippon marsh (Glais et al., 2016). Sediments of these $3 \mathrm{~m}$ long cores consist mainly of grey to black organic clay. These two cores were collected in PVC tubes (diameter $60 \mathrm{~mm}$, length $1 \mathrm{~m}$ ), protected in plastic guttering and stored under cold condi- 


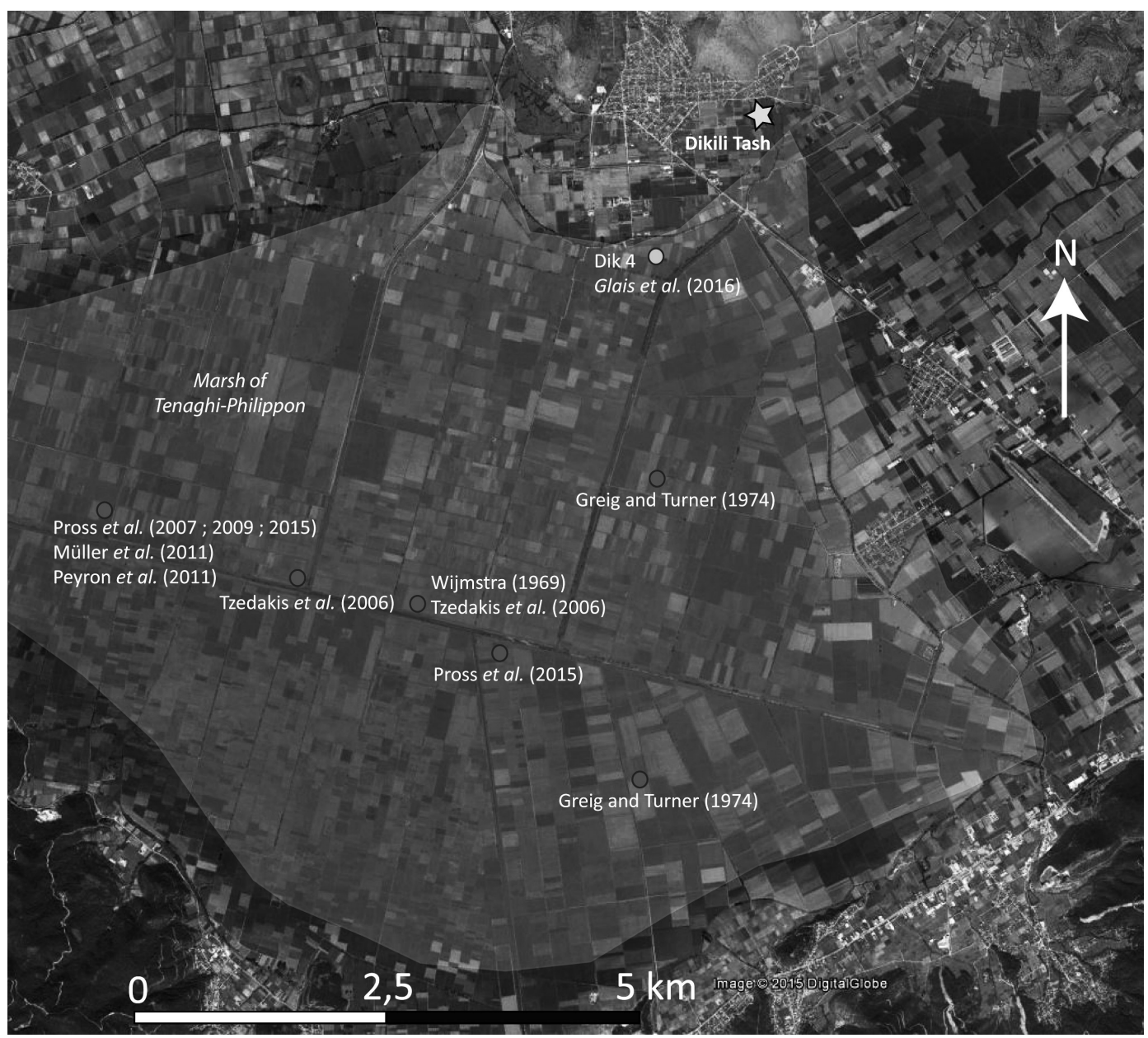

Figure 6. The Tenaghi Philippon (former) marsh, Dikili Tash archaeological sites and sample cores obtained from the marsh deposits mentioned in the references. Image from Google Earth $\left(40^{\circ} 58^{\prime} 0 \mathrm{~N}, 24^{\circ} 15^{\prime} 0 \mathrm{E}\right)$.

tions $\left(5^{\circ} \mathrm{C}\right)$ prior to laboratory description, subsampling (every centimetre) and analyses. The organic sequence in these cores did not evidence any pedological disturbance. However, other cores collected elsewhere on the field with open gouges contained sediments more compressed and much less favourable for multi-proxy analyses. In the Neolithic sites of Sidari and Khirokitia, the lack of pollen preservation kept us from acquiring similar data. On these latter sites, vegetation was documented by charcoal analyses on firewood assemblages or by peripheral fire horizons.

In central Anatolia, regional-scaled climate records are scarce. The only record published is from Adabağ marshes in the Konya Plain. However, it is insufficiently dated (only one date concerns the early Holocene: Bottema and Woldring, 1984) (Fig. 3). At higher altitudes in Cappadocia, two multiproxy records have been studied: Eski Acıgöl (Roberts et al., 2001) and Nar Lake (Dean et al., 2015). However, the chronology of these two records presents uncertainties because of either $\mathrm{CO}_{2}$ degassing (Eski Acigöl) or floating sections (Nar). The climatic reconstruction presented in Fig. 8 is based on chronological comparisons of successions of sediment facies and content (organic matter, shells, grain origin and size), studied in cores from marshes and lakes (Konya Plain and Bor Plain) as well as in sections of coastal marshes and slope deposits (Konya Plain, Tuz Gölü). This approach produces a discontinuous record which explains the geographic variability in the micro-regional and local environments in the Konya, Bor and Tuz closed plains at the foot of the Cappadocian highlands. The discontinuity is caused by the sensitivity of the three plains with regard to two signals: (1) the changes in yearly humidity (precipitation vs. evaporation) and (2) the changes in the origin of the water, i.e. exogenous runoff from the Taurus Mountains to the south vs. local rain in the plains and local runoff from the southern Cappadocian highlands. Since the sensitivity to local and regional water budget is high in these dry endorheic plateaus and plains, both the occurrences and interruptions of records provide significant information for positioning alternations and changes through time, as well as at micro-regional geographic positions. 

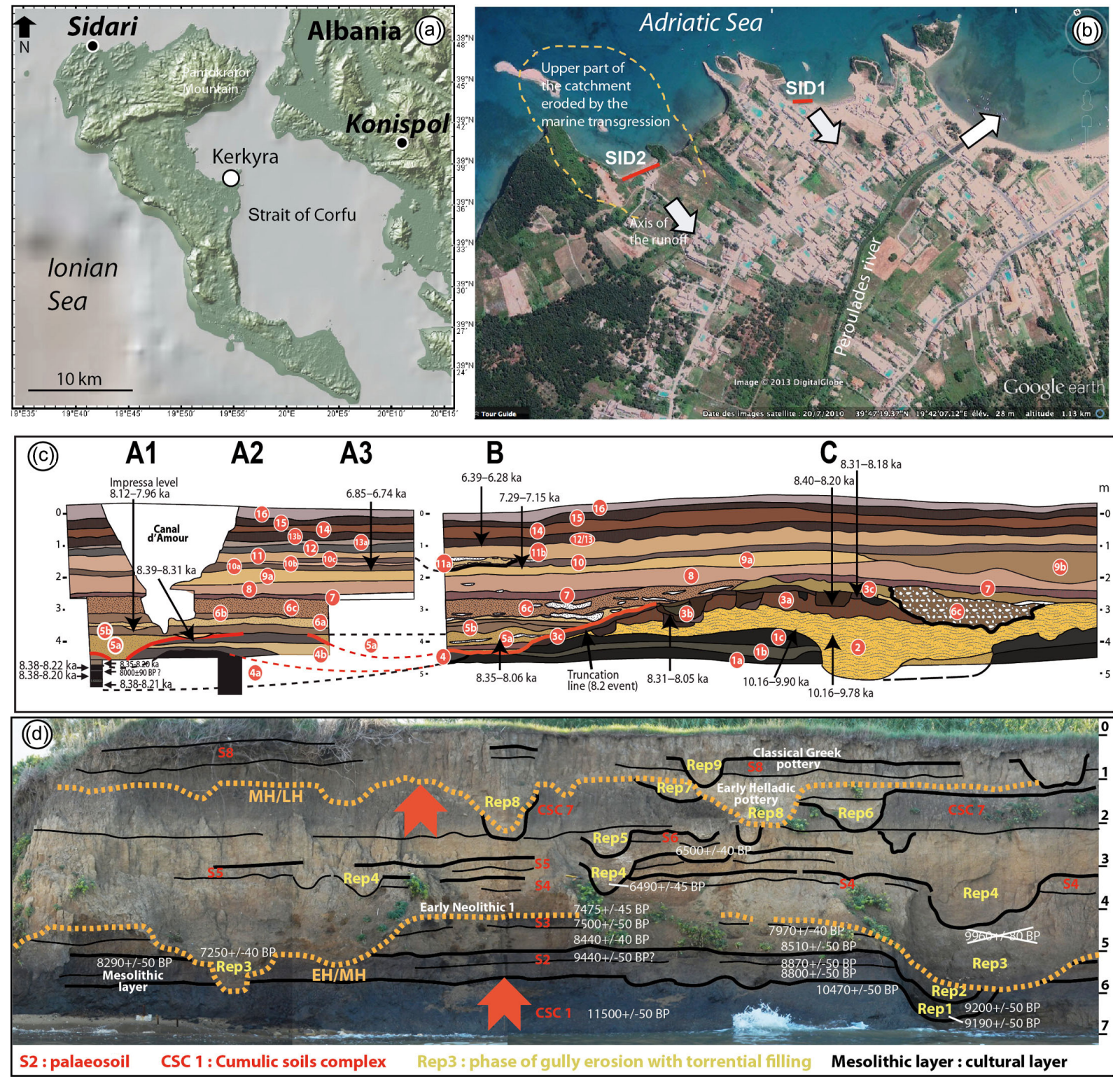

Figure 7. (a) Map of Corfu with location of the site of Sidari on the northern coast; (b) location of the Sidari 1 and 2 trenches in two small marly valleys, tributaries of the Peroulades River; (c) pedo- and chronostratigraphic contexts of the Sidari 1 sequence with the main Neolithic levels (after Berger et al., 2014); and (d) pedo- and chronostratigraphic contexts of the Sidari 2 sequence with the main Holocene lithostratigraphic disconnections.

After the start of rescue excavations in 2004, the chronology and the chronostratigraphic context of the Sidari site 1 (Sordinas, 1967, 1973) were fully rebuilt (Berger et al., 2014). Dates performed in the 1970s (on charcoals) presented standard deviations that were overly broad when compared to current international standards. Consequently, 15 AMS dates were performed on charcoals from the new excavation, including a dozen samples from the horizons of early Neolithic I and II (Table S1 in Supplement). Ten dates were performed on deciduous oak charcoal pieces, a species which is hyper-dominant in the charcoal assemblages (S.
Thiébault, personal communication, 2006). Three ${ }^{14} \mathrm{C}$ AMS dates were performed on charred seeds in the Neolithic I horizons (Poaceae vs. Cerealiae and Prunus sp.). One date was performed on a cereal seed in the Impressa Neolithic horizon. The comparison of AMS dates shows that certain dates conducted on oak charcoals are aged of the order of a century (old wood effect). At least three ${ }^{14} \mathrm{C}$ dates from samples collected in alluvial layers were associated with a significant aging; because of probable sedimentary destocking, they have been rejected. At site Sidari 2, 15 AMS dates were obtained exclusively from micro-charcoal, which is partly 


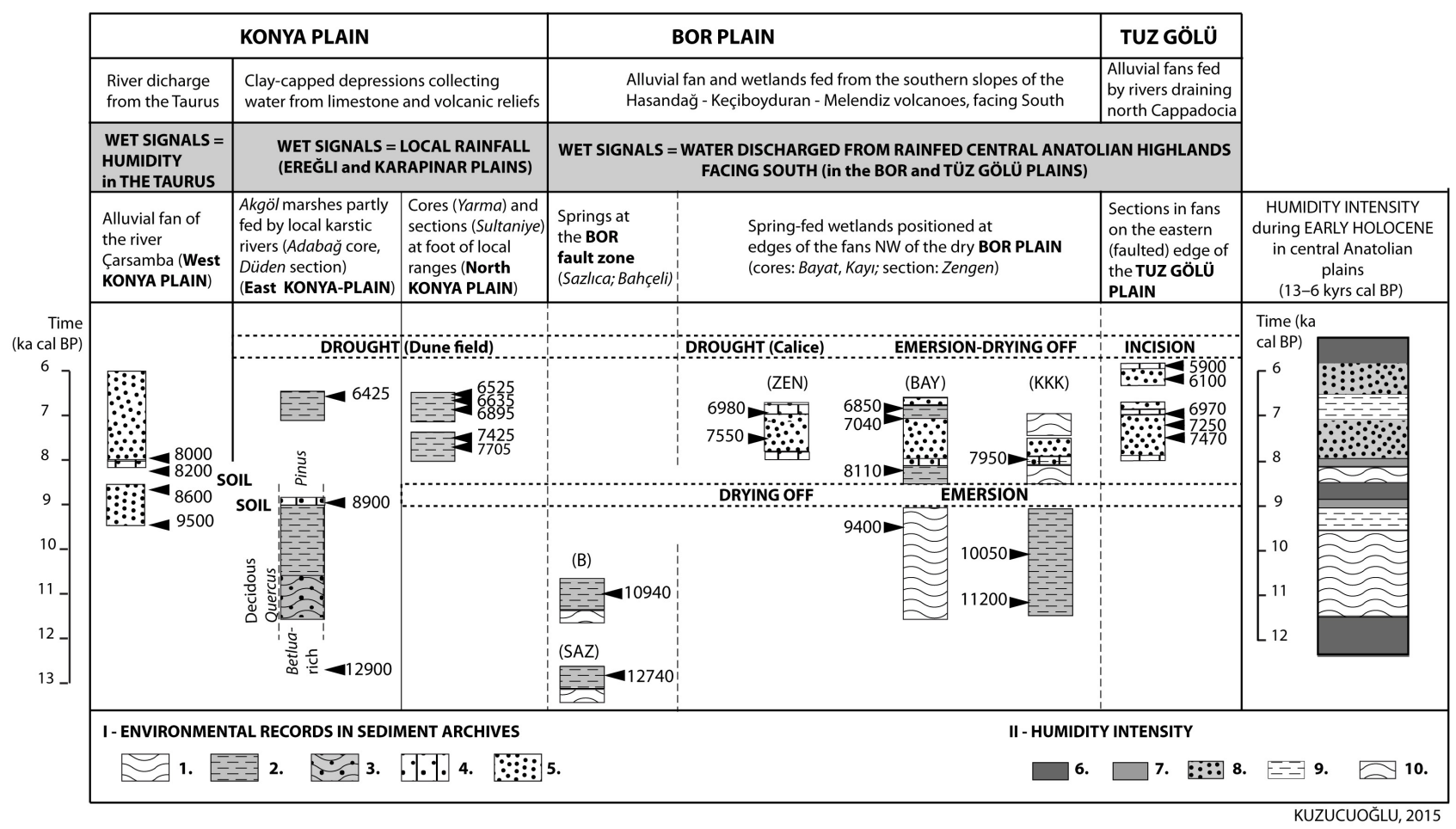

Sources are for (a) Konya and Ereğli (Bottema \& Woldring, 1984; Kuzucuoğlu et al., 1997, 1998, 1999, in prep.; Fontugne et al., 1999; Boyer et al., 2006); (b) Tuz Gölü (Naruse et al., 1997; Kashima, 2002)

Radiocarbon dates in Konya are from LSCE. AMS radiocarbon dates in Bor are from ARTEMIS/Saclay and POZNAN (PaleoMex/ArchéoMed)

Figure 8. Dated palaeoenvironmental records in the three main endorheic plains of central Anatolia: a synthesis between 12.5 and $6.0 \mathrm{ka}$ cal BP. Environmental records in sediment archives: 1, deep lake; 2, backswamps; 3, vegetated shallow marshes; 4, palaeosol; 5, alluvial fan (coarse sediment). Humidity intensity (synthesis): 6, dry to very dry; 7, emersion of watered ecosystems and soil formation; 8 , semi-arid and/or contrasted seasonal climate (high seasonal run-off); 9, humid (marshes); 10, very humid (lakes, backswamps).

identified. They were sampled in horizons rich in charcoal particulates produced by palaeo-fires.

The dates of the Khirokitia PPNB site were collected from archaeological structures which were interbedded in the Maroni alluvium at the margins of the village. They mainly concern charcoals from ashy lenses or in situ fireplaces in built structures that provide a reliable environment for dating (Table S1).

In Macedonia, the chronology of DIK 4 core is based on 11 AMS radiocarbon dates (Table 1 in Glais et al., 2016). The chronology for the Dik 12 core is based on three AMS radiocarbon datings on charcoals and organic sediment (Glais et al., 2016). Intra-site ${ }^{14} \mathrm{C}$ dates of the Dikili Tash tell and its surroundings are available in Lespez et al. $(2013,2016)$.

Regarding the central Anatolian chronology, dates are provided by several studies and places (Fig. 8). At Adabağ (Konya Plain) one ${ }^{14} \mathrm{C}$ date pre-dates a hiatus $(9.1-8.7 \mathrm{ka}$ ) interrupting a humid phase (Bottema and Woldring, 1984). The rest of the chronology in the Konya Plain (Kuzucuoğlu et al., 1997, 1999; Fontugne et al., 1999; Boyer et al., 2006), Tuz Gölü Plain (Naruse et al., 1997; Kashima, 2002) and Bor Plain (Gürel and Lermi, 2010; Kuzucuoglu et al., in preparation) consists of a total of $27{ }^{14} \mathrm{C}$ ages ( 7 dates from the
Bor Plain are as yet unpublished). ${ }^{14} \mathrm{C}$-dated samples are peat layers, palaeosol, charcoal dust from marshy environments, and calice for one sample in the Bor Plain (Gürel and Lermi, 2010). A 28th age has been obtained by optically simulated luminescence (OSL) (Kuzucuoglu et al., 1998) on sand from a fossil dune (Kuzucuoğlu et al., 1998).

\section{Results}

The results of the local investigation in the four selected studied are presented from east to west following the Neolithic expansion.

\subsection{Central Anatolia}

Questioning the role of climate on the Neolithic dynamics in central Anatolia from the PPN to PN and during the early PN during the first half of the 9th millennium cal BP means that we have to define the climatic context and evolution from 9.5/9.4 to 9.2/9.0 ka. A similar question concerns the transition phase between the $\mathrm{PN}$ and Chalcolithic ca. 8.2 and $8.0 \mathrm{ka}$ in central Anatolia (Baird, 2012). A few sites are occupied during this period in Cappadocia (e.g. Tepecik-Çiftlik 
and Köşk Höyük) and in the Konya Plain (Çatalhöyük EastWest: e.g. Marciniak et al., 2015). This transition is, however, not well known, mainly because the middle Chalcolithic period $(7.5-6 \mathrm{ka}$ ) remains under-investigated in Turkey (Düring, 2011). Instead, the cultural turning point that occurs through Neolithic Anatolia ca. 8.6 ka seems more distinct than changes happening ca. 8.2/7.8 ka (Düring, 2011; charts in Özdoğan, 2012a, b). Nevertheless, the parallelism between cultural changes and the timing of the "9.2" and "8.2" ka RCCs suggests that there may have been a relationship between climate and cultural changes during the events.

Results from geomorphological, geoarchaeological and palaeoenvironmental research during the 1990s in the Konya Plain (Kuzucuoğlu et al., 1997, 1998, 1999; Fontugne et al., 1999; Roberts et al., 1999), in the Tuz Gölü Plain (Naruse et al., 1997; Kashima, 2002), and more recently in the Bor Plain (Gürel and Lermi, 2010; Kuzucuoğlu, 2015; Matessi et al., 2016) today allow us to propose a chronological synthesis of the environmental context of the cultural dynamics between the 10th and the 7th millennium cal BP. The palaeoenvironmental records in the three closed plains of central Anatolia (Figs. 3 and 8) show evidence of alternations of humid and dry phases during the Holocene. The chronological comparison between these phases and the global climatic record shows that (a) there is a high variability in records in the humid areas sensitive to even slight changes in humidity; (b) some RCC have no correspondence in the environmental records; and (c) when a signal occurs in parallel with one of the RCC, the signal varies in nature and magnitude (soil signaled by roots and vegetation, emersion out of wetlands, drying off, drought, etc.). The comparison between the locations of the sediment archives in such an evaporationsensitive context as that of the central Anatolian endorheic plains shows that the geomorphologic settings of the records (cores and sections) control the signal, i.e. the type and sensitivity of the drying/wetting wetlands: sub-surficial water in alluvial fans, marshes fed by springs at the external edges of alluvial fans, springs along faults, karstic outflows, ice and snowmelt from highlands, rivers etc. (Fig. 8). Both the topographic specificities of the ecosystems and the spatial variability in the air masses transporting humidity in the area contribute to the importance of the regional and local scales in the palaeoenvironmental records.

According to these records, the general environmental evolution in the region during the early Holocene is the following (Fig. 8):

- After the onset of the Holocene at ca. 11.4 until 9.5$9.0 \mathrm{ka}$, springs and rivers in the Konya Plain collect water originating in precipitation and snow/ice melt in the Taurus Mountains. This water is also discharged by the karstic network of the range. This water accumulates in shallow depressions stretching at the foot of the Taurus Mountains along the Konya-Ereğli-Bor plains. For example, the expansion of the Akgöl backswamps at the southern border of the Ereğli Plain (Bottema and Woldring, 1984) is such a signal of a humidity rise triggered from the Taurus highlands.

- Towards $9.5 \mathrm{ka}$, alluvial fans start to expand over the Last Glacial Maximum marls forming the Konya Plain bottom (Çarsamba and Karaman rivers: Boyer et al., 2006), as well as in the Çiftlik Plain up in the Cappadocian volcanoes (Kuzucuoğlu et al., 2013). This riverdynamics-related change is the only possible signal of a climatic change contemporaneous with the $9.2 \mathrm{ka} \mathrm{RCC}$. This signal is produced by a change in run-off indicating a rise in spring water and a possible increase in seasonal temperature contrast. Such a change would have produced enough snow and ice meltwater to initiate the growth of Holocene alluvial fans over the plain bottoms. During this period, the Adabağ pollen record is marked by the expansion of an arboreal vegetation dominated by deciduous Quercus (Bottema and Woldring, 1984). This alluvial fan initiation corresponds to the abandonment of PPN sites in Cappadocia (Aş1klı) and Konya (Boncuklu, Can Hasan III). One or several centuries later, late PPN sites (Çatalhöyük East in Konya; Tepecik-Çiftlik in Cappadocia) are founded at locations close to the expanding alluvial fans.

- The soil dated to $9.0-8.9 \mathrm{ka}$ in the Adabağ core possibly marks the end of the period of change which started ca. $9.5 \mathrm{ka}$. With the exception of the Çarsamba fan, which continues to grow until $8.6 \mathrm{ka}$, the absence of sediment record dated to the first half of the 9th millennium cal BP suggests that the plains were dry, with little or no water input from the central Anatolian highlands (Cappadocian volcanoes).

- The second half of the 9th millennium cal BP is characterised in the Konya Plain by the interruption of the torrential dynamics in the Çarsamba fan between 8.6 and $8.2 \mathrm{ka}$. During this period, the marshes along the edges of the Altunhisar fan in the Bor Plain seem to have dried off too, although not for as long since they are well watered (lakes and backswamps) before $8.2 \mathrm{ka}$, when they dry up again. In a generally dry 9th millennium cal BP in central Anatolia, this dry-wet-dry alternation in the northern shores of the Bor Plain (Bayat and Kayı cores), as with the continuing record at Adabağ (fed by Taurus karstic waters), corresponds to local signals.

- The $8.2 \mathrm{ka} \mathrm{RCC}$ is present in central Anatolian records as a one-century-long dry signal interrupting backswamps and lakes around the Altunhisar fan between 8.1 and $7.9 \mathrm{ka}$.

- The most humid climatic phase in central Anatolia starts ca. $7.9 \mathrm{ka}$ and lasts until ca. $6.5 \mathrm{ka}$, which marks the beginning of the mid-Holocene dry phase (Kuzucuoğlu, 2015; Matessi et al., 2016). 


\subsection{Khirokitia (Cyprus)}

Results from the foot of the eastern slope of the site, next to the Maroni River channel, allowed recognition of at least two major sedimentary events that occurred during the occupation of the site.

The first of these events is a major channel incision concurrent with torrential stream discharges (Fig. 5). It is marked at the foot of the eastern slope by the deposition of a $3.5 \mathrm{~m}$ thick layer of densely packed, non-sorted, rolled stones and gravel at the base and more stratified but relatively fine-grained gravel and sand near the top. Deposits here underlie the archaeological remains in this sector and unconformably overlie Miocene fluvio-marine sediments. One feature of note is the presence of Neolithic stone tools as well as charcoal lenses, ash and fine fragments of burnt bones and mud brick within the alluvial discharge near the top. A radiocarbon date obtained on ash specks from this unit indicates an age of $8518 \pm 55$ years BP (Table S1).

The second and more prominent sedimentary event is a substantial erosional episode. It is particularly visible in the middle of the archaeological sequence overlying deposits of the first sedimentary event at the foot of the eastern slope (Fig. 5). A 0.6 to $0.8 \mathrm{~m}$ thick stratum of angular limestone gravel and other archaeological debris divide the $4 \mathrm{~m}$ high archaeological sequence in this area into two parts. Archaeological structures of the lower part are deeply gullied and appear to be less preserved than in the upper one. Two radiocarbon dates, obtained on charcoal lenses from the debris of two superimposed houses sited on top of the erosional layer, propose the ages of $8276 \pm 55$ and $8248 \pm 53$ years BP, respectively (Table S1). A $3 \mathrm{~m}$ thick sequence of intersected clusters of alluvial discharges as well as side gully debris observed on the river section, slightly upstream of the studied archaeological sequence and opposed to it (Fig. 4b), might also be attributed to this later episode of erosion and surface flows. Here alluvial deposits are composed of loosely packed and unsorted stones, gravel and coarse sand. Gully debris reworked from the surrounding slopes is more abundant at the base of the sequence. It consists of compacted whitish to dark-grey loam, mixed with small white angular and black rounded stones mixed with flakes of flint, bone fragments and lenses of charcoal. This gully debris was radiocarbon dated to $8105 \pm 55$ years BP (Table S1). The top of the sequence is capped by alluvial dark-grey sandy silt, $0.8-1.2 \mathrm{~m}$ thick, and then by grey-brown loam, indicating subsequent decrease in the energy of flows. However, incision during the late Holocene led to the lowering of the river channel bed, producing a suite of at least two younger river terraces in the area.

The two sedimentary events described above indicate that the region of Khirokitia experienced strong modifications in the hydro-geomorphological configuration around 8.5 and, more particularly, $8.1 \mathrm{ka}$. The morphological distinction between both these two events on the one hand, and what could have been the situation before they occurred on the other hand, is difficult to establish adequately in such a dissected area where older terraces are obscured by younger sedimentation and subsequent erosion. However, the nature and the extent of the events observed indicate erratic and heavy rainfall conditions that in all probability seem to have occurred on a wider regional scale. Not far from Khirokitia, downcutting by $6 \mathrm{~m}$ was followed by a period of aggradation and alluviation between 8.3 and $7.9 \mathrm{ka}$ in the Vasilikos Valley near Kalavasos (Gomez, 1987) (Fig. 4a). A similar sequence was also observed in the Middle Jordan Valley (Jordan), where marshy deposits corresponding to the beginning of the Holocene were deeply truncated and then recovered after by the red soils associated with the first settlers of the late Neolithic period (Hourani and Courty, 1997; Hourani 2005, 2010) (Fig. 2).

Notwithstanding the role of humans in the weakening of the soil cover, tectonic activities that may also have facilitated the incision of the riverbed and (or) changes in the direction of the stream runoff as well as lowering of the riverbed both indicate that the Neolithic landscape at Khirokitia resulted predominantly from climatic factors. At Khirokitia, if this period of surface erosion and torrential discharges were to be integrated into a wider regional or global scale, it might then be seen as a regional expression of the worldwide-identified $8.2 \mathrm{ka}$ event. Here, the first cultural implication that can be drawn from this erosional event is the shift and contraction in the village space along with the major changes observed in the botanical and zoological records towards the end of the 7th millennium cal BC. The attribution of the end of the PPN occupation at Khirokitia to the $8.2 \mathrm{ka}$ event (Weninger et al., 2006) thus cannot be sustained.

\subsection{Eastern Macedonia}

In eastern Macedonia, investigations have been performed on the edges of Tenaghi Philippon marsh. This large marsh located in northern Greece has been subjected to numerous palaeoenvironmental studies (Wijmstra et al., 1969; Greig and Turner, 1974; Tzedakis et al., 2006; Pross et al., 2009; Peyron et al., 2011) which constitute reference records for the environmental history of the eastern Mediterranean area (Fig. 6). The results of these studies have been focused mainly on climate impact on vegetation cover. In order to track the climatic changes as well as the impact of the Neolithisation process, which is here dated from $8.5 \mathrm{ka}$ onwards (Lespez et al., 2013), palaeoenvironmental investigations have been performed from the archeological site to the marsh.

The pollen records (Fig. 9) indicate a general decrease in steppe taxa (Artemisia and Chenopodiaceae) and the steady increase in other herbaceous plants such as Cichorioideae, and other ruderal taxa suggesting a return to more humid conditions at the end of the Younger Dryas (ca. 11.7-10.2 ka). This is also supported by the recorded appearance of lime 


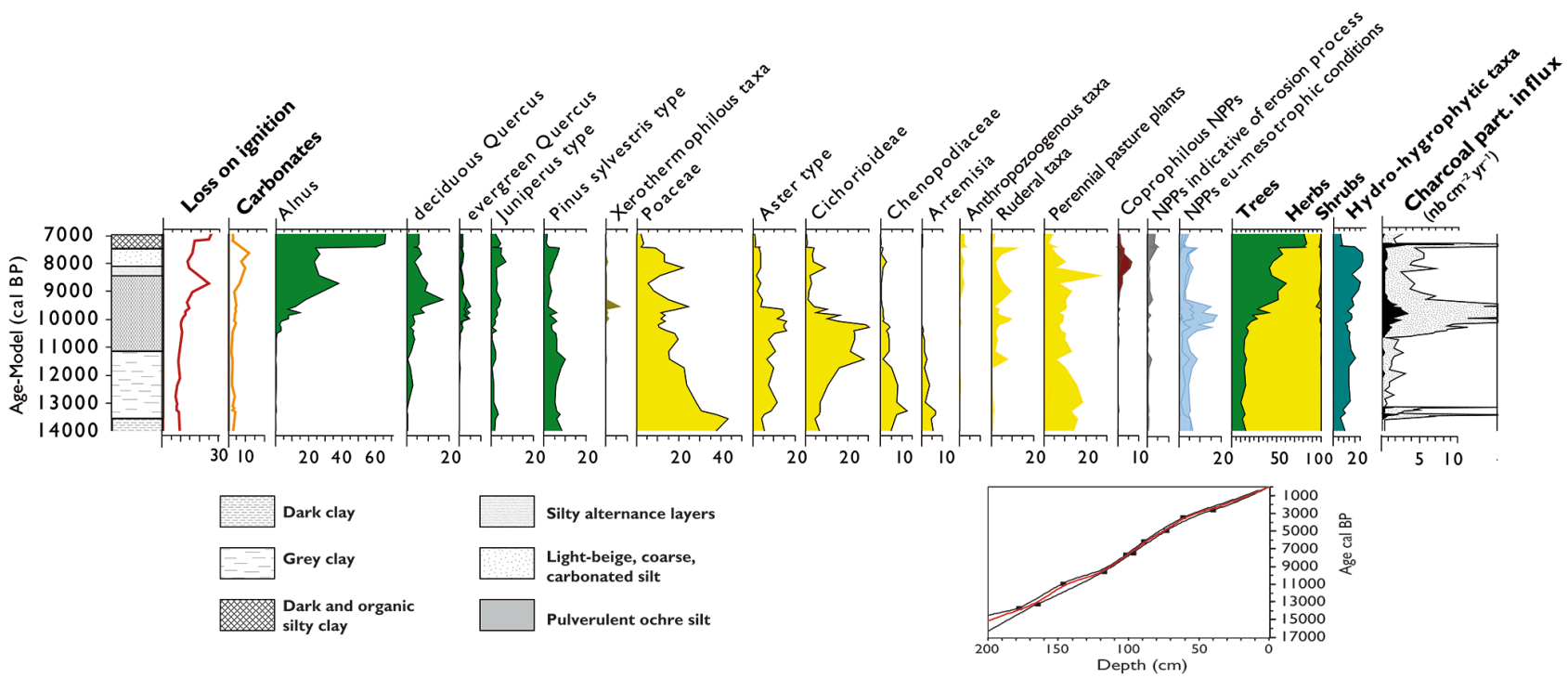

Figure 9. Diagram from the Dik4 core with its age-depth model. Loss on ignition and carbonate content of the sediment expressed in \% of the total sediment. Charcoal influx expressed in $\mathrm{cm}^{-2} \mathrm{yr}^{-1}$. Selected pollen and NPP groups expressed in \% (see Glais et al., 2016): (1) xerothermophilous taxa (Ephedra fragilis type, Erica arborea type); (2) ruderal taxa (Asphodelus albus type, Asphodelus fistolosus type, Boraginaceae, Cannabis/humulus type, Cardueae, Centaurea nigra type, Fumaria officinalis, Malva sylvestris type, Rubiaceae, Rumex acetosa type); (3) anthropozoogenous taxa (Plantago lanceolata type, Plantago coronopus type, Polygonum aviculare type, Urtica dioica type, Vicia type); (4) perennial pasture plants (Apiaceae, Brassicaceae, Caryophyllaceae, Fabaceae undiff., Gentianella campestris type, Helleborus foetidus type, Jasione type, Primulaceae); (5) coprophilous, NPPs (Cercophora sp. type 112, Podospora sp. type 368, Sordaria sp. type 55A, Sporormiella sp. type 113, Coniochaeta cf. lignaria type, Ustulina deusta type 44); (6) eumesotrophic NPPs (Ceratophyllum sp. type 137, Botryococcus type, Gloeotrichia type 146, Spirogyra type, Neorhabdocoela undiff., type 128A, type 18, type 151, Zygnema type); (7) meso-oligotrophic NPPs (Anabaena sp. type 601, Rivularia type 170); (8) NPPs indicative of erosive processes (Glomus cf. fascilicatum type 207 and Pseudoschizaea circula type); (9) NPPs indicative of fire events or dry conditions (Chaetomium sp. type 7A, Neurospora sp. type 55c, Pleospora sp. type 3B, type 200).

trees, an increase in NPPs indicative of eumesotrophic conditions and a slight but continuous deciduous oak expansion. These observations are consistent with the regional climatic model (Kotthoff et al., 2008; Peyron et al., 2011). Around $10.2 \mathrm{ka}$ the pollen indicates a gradual and long-term change with great development of arboreal vegetation and the decline of open vegetation cover (arboreal polle n/non-arboreal pollen (AP/NAP) ratio increases from $20 \%$ to more than $50 \%)$. Wetter and warmer conditions have favoured the expansion of all broad-leaved trees, such as oaks and alders, and subsequently the appearance of mesophilous taxa such as ostryas, birches, ulmus and evergreen oaks. After a delay in comparison with western Greece (Lawson et al., 2004), this expansion indicates the onset of interglacial conditions. In this context, the first macrocharcoal peak extended (10.6$9.3 \mathrm{ka}$ ) corresponds to the biomass development in a still incomplete wooded landscape. Forest expansion was punctuated by a short-term centennial-scale drier climatic events (9.6-9.3 ka) distinguishable at regional (Kotthoff et al., 2008) and local scale by the increase in xerothermophilous taxa and evergreen Quercus (Glais et al., 2016).

After 9.3-8.7 ka, the vegetation cover is marked by a peak in deciduous oaks; the appearance of fir on the top of sur- rounding mountains; a decrease in Poaceae, Aster type and Cichiorioideae taxa; and the retreat or even disappearance of woody species limited to Mediterranean contexts. This spread of forest cover was interrupted around 8.7-8.3 ka. The decrease in trees and increase in herbs could indicate the impact of the $8.2 \mathrm{ka} \mathrm{RCC}$, but this period also shows the first signs of human impact in the early Neolithic. The peak in coprophilous NPPs, ruderal taxa and NPPs indicative of erosive processes are certainly due to the early Neolithic settlement implantation in Dikili Tash (Lespez et al., 2013; Glais et al., 2016) benefitting from pristine forested environment with multiple available resources. This is attested to in the NPP record, not only by a first coprophilous species peak but also by a decrease in deciduous forest species and increase in herbaceous taxa on the edge of the marsh. Furthermore, at the bottom of the site (Dik 12), high-percentage cereal pollen (around $9 \%$ at $8.4 \mathrm{ka}$ ) and the increase in ruderal taxa make it clear the anthropogenic impact on vegetation cover was associated with agropastoral activities.

Nevertheless, the conjunction with the $8.2 \mathrm{ka}$ event that is well established at the regional scale a few decades afterwards makes the interpretation more complex, and other causes can be evoked to explain the pollen and NPP records. 

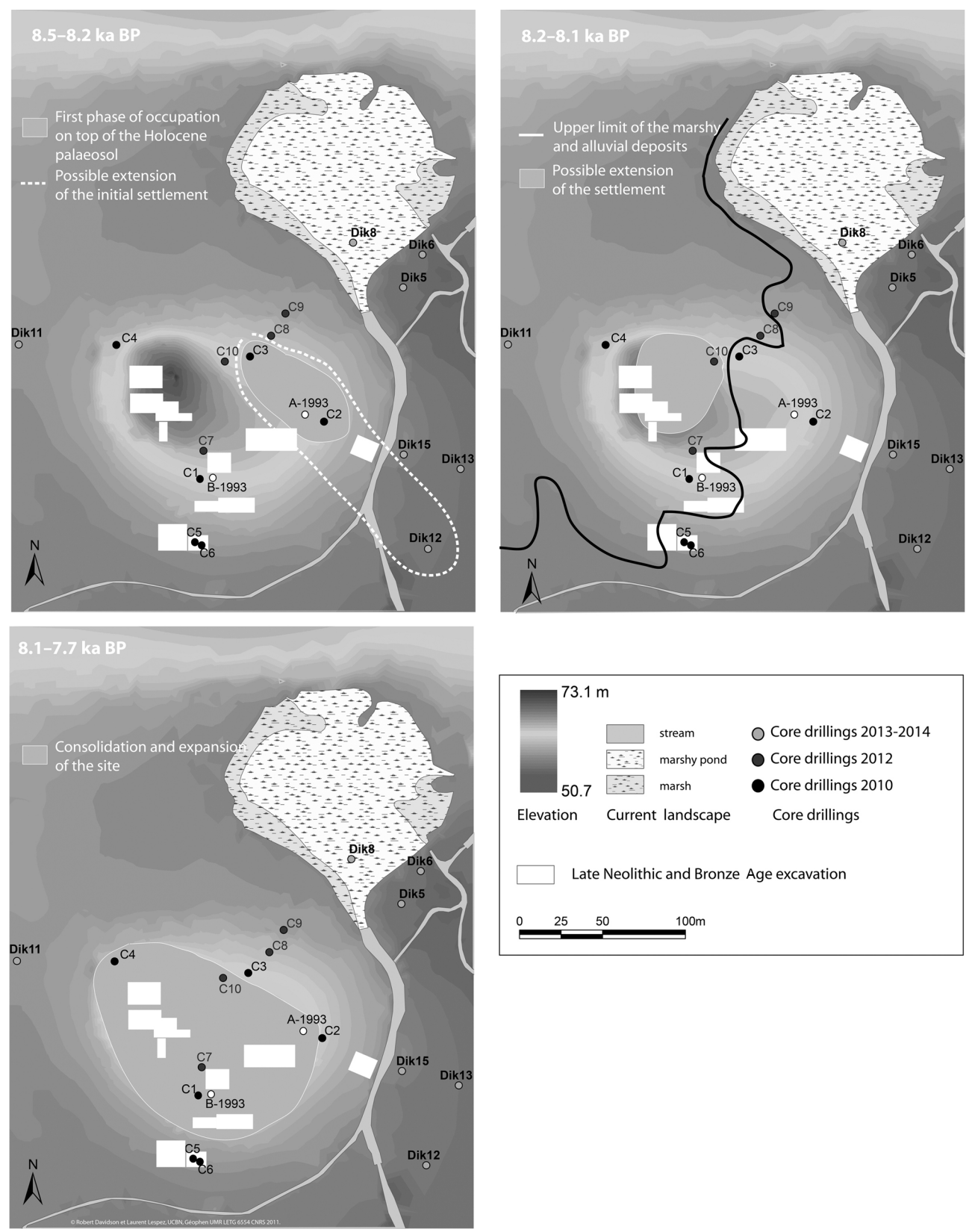

Figure 10. Map of the core drillings around Dikili Tash site and interpretation of the settlement dynamics during the early stages of the Neolithic.

The high percentage of hydro-hygrophytic taxa on the edge of the marsh suggests a contemporaneous rise in the water table level in a drier period well assessed at the regional scale (Pross et al., 2009). Furthermore, marshy deposits or oncolytic sands layer are interstratified within the anthropogenic layers of the first levels of occupation on several cores (Lespez et al., 2013). It indicates a rise of the water table of the little pond located at the bottom of the site, which is fed by an exsurgence in the marble slopes which dominate the site (Fig. 10). At C3, it corresponds to two high stands. The first one is dated at $\mathrm{C} 3$ after $8.38 / 8.17 \mathrm{ka}$, while the second is dated at $\mathrm{C} 2$ and $\mathrm{C} 3$ around $8.0-7.9 \mathrm{ka}$. Additionally, the geomorphological observations in the small valley of Dikili Tash which runs to the marsh show development of detrital carbonate sedimentation. In the Dik4 core, it corresponds to carbonate silty layers which interrupted the organic sedimentation. This suggests an increase in flood flows from the small stream which runs from the Dikili Tash pond during the period 8.2-7.8 ka. These observations are close to the results obtained at Lake Doirani (130 km WNW) (Fig. 2), which show a relatively high lake level during this period (Zhang et al., 2014). From the beginning of the 9th millen- 
nium cal BP, the vegetation cover shows the return of some pioneers or mesophilous taxa (hazel, elderberry and black haw trees), or their appearance (ash and broom) shortly before a closing landscape phase. Locally, the riparian vegetation increases considerably in relation to a drier environment due to (1) previous detritic sedimentation input which fills the edge of the marsh, (2) the water level decrease which begins from ca. $7.5 \mathrm{ka}$, and (3) the forest cover expanse in the region because of climatic amelioration (Pross et al., 2009).

\subsection{Northwestern Greece-Corfu}

A precise field geomorphological and palaeopedological approach, favoured by the presence of interbedded archaeological levels and charcoal beds which are systematically radiocarbon-dated, allowed the construction of a solid micro-regional chronostratigraphic framework. The CPDF analysis provides a probabilistic assessment of centenniallength sedimentary aggradational episodes interrupting early Holocene active pedogenic and landscape stability development favoured by a more humid Mediterranean climate within two individual catchments.

The Sidari 1 archive presents a $5 \mathrm{~m}$ pedosedimentary sequence depth. The rescue archaeological excavation operated in the mid-2000s had uncovered eight main archaeological layers from the Mesolithic to the Helladic periods that are interbedded in a complex polyphased sequence, with 16 main phases of river and colluvial activity and pedogenesis in five millennia (Berger et al., 2014) (Fig. 7c). Sidari 2 is a natural transversal trench of a small dry valley, $80 \mathrm{~m}$ wide and $7 \mathrm{~m}$ deep, entrenched in cemented Pleistocene formations. The deposits are actively eroded by the current sea level change, which allows a full observation of the Holocene filling to be made. A first chronostratigraphical view of the sequence identified two abrupt limits at the early to mid-Holocene (around $8.2 \mathrm{ka}$ ) and mid- to late Holocene periods (around $4.0 \mathrm{ka}$ ) (Fig. 10d), which refer to the recent tripartitioning of Holocene period (Wanner et al., 2008). In this paper we focus only on the lower half of the filling, consisting of a thick cumulic soil complex and the beginning of the mid-Holocene period marked by a rapid breakdown of pedosedimentary conditions, leading to a very erosive and detrital activity in the small marly basins over one millennium.

The Sidari 2 local chronostratigraphy building clearly presents a stairway age-depth model with three phases of high acceleration of sedimentation rate (Fig. 11b): from 10.4 to $10.0 \mathrm{ka}$, from 9.5 to 9.0 , and after $8.4 \mathrm{ka}$. This environmental temporality clearly represents millennial pedogenesis/incision-aggradation rythmicities, particularly well illustrated in the Sidari 2d profile (Fig. 11a), which represents a morphopedological synthesis of the events' succession. A systematic sedimentological and geochemical multiproxy approach that describes pedoclimatic conditions, hydrosedimentary environments, detrital fluxes and some ecological factors (fires) is still yet to be done. Hydrosedimen- tary and palaeopedological interpretations presented in this paper should be viewed as preliminary.

The biostability phases that develop between erosive phases discussed are expressed in geological records of catchment heads by development of black, deep soil (phases I, III and V, Fig. 11a), often decarbonated and leached, as observed at the microscopic scale in Sidari 1 (Berger et al., 2014). These kinds of pedogenesis and associated pedofeatures (hyaline cutans) illustrate a dense forest cover that is highly protective for soils (Macphail et al., 1987; Kühn, 2003). Local charcoal assemblages (Delhon and Thiebault forthcoming) and the regional pollen spectra (Bordon et al., 2009; Triantaphyllou et al., 2009; Combourieu-Nebout et al., 2013; Glais et al., 2016) reveal vegetation dominated by mesophile deciduous oak forest. At the start of the Holocene, a first, broadly stable and humid, phase is favourable to the development of a thick leached and humic cumulic palaeosol (Berger et al., 2014). The second half of the early Holocene is, however, punctuated by a succession of abrupt breaks in the hydromorphological functioning of the marly valleys. The duration of these breaks is century-scaled, and their occurrence presents a quasi-millennial cyclicity. The breaks are characterised in the field by a sudden cessation of soil formation processes, synchronous with deep gullies cutting each other when three Early Holocene climate events occur (Fig. 11a). These gully activities (phases II, IV, VI) are followed by a rapid-filling phase of lighter-tone alluvio-colluviation that is often still decarbonated (association of inherited soil material and marls) and whose palaeodynamics can be characterised by analysis of the sedimentary fill mode: (1) the slick or lenses of sand and gravel deposits, rich in small wellrounded nodules of clay soil, are associated with concentrated runoff causing gullying and sapping upstream soil formations (Fig. 11cd-IVb1-VIb) and (2) finer well-sorted deposits, often micro-laminated, associated with finer and regular rainfall generating diffuse runoff (Fig. 11e-VIg). Therefore, we explain the formation of these two facies by the expression of different rainfall on largely bare surfaces by fire (presence of regular charcoal bed). The transition between RCC events and the pedological stabilisation of the valley is generally dominated by more regular rainfall (fine granularity, diffuse laminations), as in the $8.2 \mathrm{ka}$ event.

The 10.4-9.75, 9.5-9.1 and 8.35-7.9 ka active periods are evidenced in cumulative probability density function plots (CPDF) (Fig. 11f). We interpret these morphological and hydrosedimentary signatures, regularly recorded in alluviocolluvial archives at Sidari, as the manifestation of RCCs, which seem to form the rhythm of the evolution of Holocene northern Mediterranean valleys.

These results suggest that data provided by continental hydrology, soils, and vegetation dynamics studied on the micro-regional scale may be good records of potential impacts of climate and of development of human societies. These new data establish the necessity of always reasoning, from contextualised data, not to overplay temporal CPDF- 

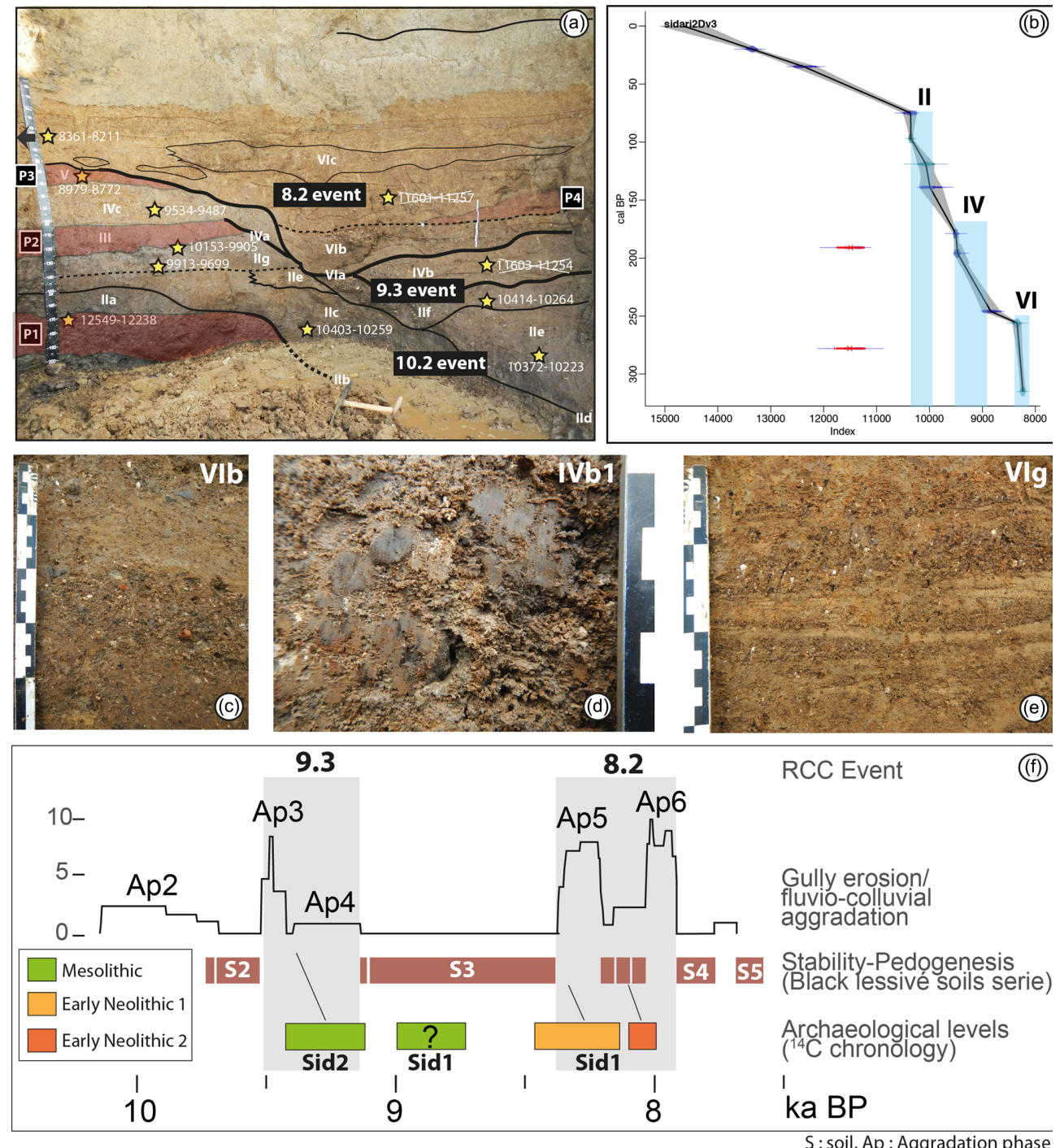

Figure 11. (a) Middle-lower pedosedimentary sequence of Sidari 2 with early Holocene palaeosols (P1-P4), aggradation and gully phases (IIa-VIc). Yellow stars: AMS radiocarbon dates. (b) Stairway age-depth model with three phases of high acceleration of sedimentation rate (phase II: 10.4-9.9; phase IV: 9.5-8.9; and phase VI: 8.4-8.1 ka). (c) Field photo of gravel and sand filling of the 9.2 ka event gullying. (d) Field photo of the $9.2 \mathrm{ka}$ event gully filling with numerous rounded clay aggregates eroded in the upper catchment. (e) Field photo of the upper part of the $8.2 \mathrm{ka}$ event filling with a regular alternation between silty and sandy beds. (f) CPDF of Sidari 1 and 2 sites (33 AMS dates). Palaeosols are located between main active peaks. Archaeological layers are represented as temporal coloured segments to distinguish their cultural attribution.

type constructions, which are sometimes too schematic and occasionally disrupted by bias related to the organic material used for the ${ }^{14} \mathrm{C}$. Indeed, we observe a constant time lag between chronocultural and morphological data (from $100 / 150$ years), whose origin is probably to be found in the old wood effect (almost a predominance of oak in charcoal assemblages). The Sidari 2 Mesolithic occupation centred on the $9.2 \mathrm{ka}$ event is associated with a short intermediate RCC pedogenic episode. The new Sidari chronostratigraphical context does not identify one Mesolithic horizon but probably three successive ones. Cultural continuity pro- posed by Sordinas $(1969,2003)$ is only apparent, as produced by geomorphological impacts of the $8.2 \mathrm{ka}$ event (Berger et al., 2014). The early Neolithic I "monochrome" occupation sets up on the palaeosol (S3) before being partially eroded (Fig. 11e), and the last diffuse occupation levels of early $\mathrm{Ne}-$ olithic I then interbedded in the first aggradation levels of the 8.2 ka event (AP5). Finally, the early "Impressa" Neolithic II level is clearly associated with the intra- $8.2 \mathrm{ka}$ episode of soil stabilisation in Sidari 1 and then covered by the second stage of alluvial aggradation (AP6). If we think in radiocarbon time, the gap initially mentioned by Sordinas (1969) be- 
tween the two horizons of early Neolithic (Monochrome and Impressa) is very brief (a few decades at most). This gap is much more marked in the sedimentary archives studied, as amplified by the very rapid aggradation process of the $8.2 \mathrm{ka}$ event. This second peak of 8.2 ka hydrosedimentary activity (AP6) seems to correspond to a durable site abandonment (until late Neolithic) (see Berger et al., 2014).

\section{Discussion about early to mid-Holocene RCC impacts on terrestrial hydrosystems and human societies at the northeastern Mediterranean scale}

The results obtained on the four sites studied assess the local environmental changes which can be linked to the RCC changes. In particular, they underline the sensitivity of hydrosystems and vegetation to climatic changes at a centennial scale. We show that the SH cooling event - correlated with glacial outburst in the North Atlantic, low values of total solar irradiance and $\mathrm{K}+$ records in Greenland ice cores has a major impact on the functioning of central to eastern Mediterranean continental hydrosystems (Fig. 12a).

The $9.2 \mathrm{ka}$ event matches one of the early Holocene meltwater pulses at $9.17 \pm 0.11 \mathrm{ka} \mathrm{BP}$ (Teller et al., 2002), which probably triggered a slowdown of thermohaline circulation. In the Asian monsoon domain (Qunf and Dongge caves) stalagmites show a positive anomaly in $\mathrm{d}^{18} \mathrm{O}$ calcite at $9.2 \mathrm{ka}$, reflecting lower monsoon precipitation (Fig. 1). The duration of the event is less than 150-200 years in all records discussed by Fleitmann et al. (2008). A recent metadata analysis of Holocene European river activity highlights the current lack of well-dated records for the early Holocene with only two Iberian flood clusters (9.5-9.2 and ca. 9.0-8.8 ka: Benito et al., 2015), in phase with high lake levels in the Jura Mountains and the northern French Prealps (9.55-9.15 ka: Magny, 2004). Both records likely reflect their high sensitivity to North Atlantic circulation. In the Sidari 2 valley, a large signal of gully erosion and vertical aggradation is synchronous to the record of European lakes and Iberian rivers, with two activity peaks between 9.5 and $9.1 \mathrm{ka}$ (Fig. 1). Comparable signals before 9.0/8.9 ka do not occur in the hydrosystems of the central Anatolian plateaus (Fig. 8), which respond to high humidity in the Taurus Mountains that feeds the high water levels in lakes and marshes located at the foot of the Taurus Mountains. However, the strong drying signal from 9.0/8.9 $\mathrm{ka}$ is well registered by the hydrosystems in Sidari and central Anatolia as well as by the vegetation cover in the Aegean and southeastern Balkans areas.

The $8.2 \mathrm{ka}$ Hudson Bay event is recorded at all the sites presented here. The $8.2 \mathrm{ka}$ Hudson Bay event, recorded at all the sites presented here, occurs occurs during a long cool interval beginning ca. $8.6 \mathrm{ka}$ (Rohling and Pälike 2005). Like the northern Aegean and Ionian terrestrial archives discussed by Weninger et al. (2014) and Flohr et al. (2016), we discuss below the bi-partitioning of the event in an earlier phase (a

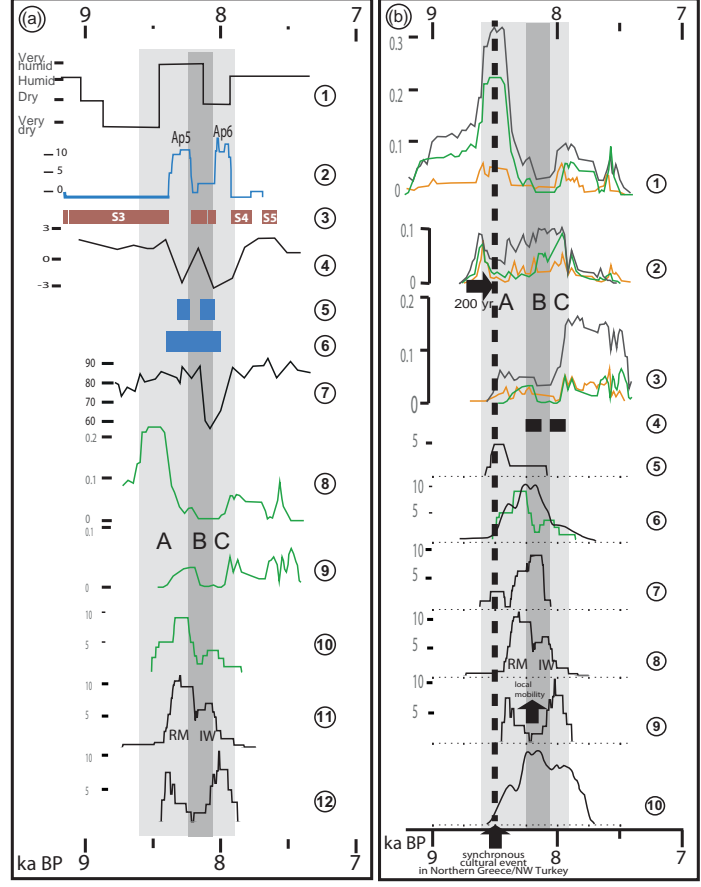

Figure 12. (a) Comparison of regional hydroclimatic pattern for Anatolia and Northern Aegean areas with micro-regional and main sites cumulative probability density: 1 , endorheic plains of central Anatolia (Kuzucuoglu, this paper); 2, gully erosion/fluvio-colluvial aggradation in Sidari 1/2 (Berger, this paper); 3, soil formation in Sidari 1/2 (Berger, this paper); 4, Lake Maliq pollen-based temperature of the coldest month (Albania; Bordon et al., 2009); 5, oncolith deposits in Dikili Tash swamp (Macedonia; Lespez et al., this paper); 6, detritism in Lake Dojran (Macedonia) (Zhang et al., 2014); 7, Tenaghi Philippon tree pollen (\%) (Macedonia; Pross et al., 2011); 8, central Anatolian late Neolithic sites (short-lived dates, $n=123$ ); 9, northwestern Turkey (short-lived dates, $n=83$ ); 10, Nea Nikomedia (Macedonia)(12 short-lived dates) (Pyke and Yiouni, 1996); 11, Sidari (Corfu) (12 charcoal, 3 short-lived dates (Berger et al., 2014) and in progress; RM: red monochrome ware; IP: Impressa ware); 12, Dikili Tash (11 charcoal dates) (Macedonia; Lespez et al., 2013). (b) Comparison of time dynamic of Neolithisation from central Anatolia to Corfu: 1, central Anatolia, all $n=285$, short-lived $n=123$ (after Flohr et al., 2016); 2, western Anatolia, all $n=64$, short-lived $n=31$ (after Flohr et al., 2016); 3, northwestern Turkey, all $n=136$, short-lived $n=83$ (after Flohr et al., 2016); 4, strong decline of site occupation in Tell Sabi Abyad (northern Syria) (from Weninger et al., 2014); 5, Paliambala (five dates, after Karamitrou-Mentessidi et al., 2013); 6, Nea Nikomedia, Thessaly (16 dates; Weninger et al., 2006) (12 dates, "short-lived"; Pyke and Yiouni, 1996); 7, Mavropigi-Filotsairi, Macedonia (12 dates, after Karamitrou-Mentessidi et al., 2013); 8, Sidari, Corfu (15 dates (Berger et al., 2014) and in progress; RM: red monochrome; IP: Impressa ware); 9, Dikili Tash, Macedonia (11 dates) (Lespez et al., 2013); 10, Achilleion, Thessaly (44 dates) (Weninger et al., 2006).

cold phase from $8.5-8.4$ to $8.2 \mathrm{ka}$ amplified during a later phase (a RCC at $8.2-8.05 \mathrm{ka}$ ) by the Hudson Bay outburst, followed by a third sub-phase between 8.05 and $7.9 \mathrm{ka}$ in the 
northern Greek and central Anatolian archives that we refer to as "C" (Fig. 12a).

\subsection{Sidari/Dikili Tash and the early Holocene northern Greece/southern Balkan regional pattern}

The increase in erosion and fluvial activity observed on both archaeological sites around $8.2 \mathrm{ka}$ has also been observed elsewhere in northern Greece such as in the Lake Prespa (Panagiotopoulos et al., 2013) and Lake Doirani (Zhang et al., 2014) (Figs. 2, 12a) areas. This confirms the trends of increase in soil erosion and sediment transfer to the wetland around $40-41^{\circ} \mathrm{N}$ during the $8.2 \mathrm{ka}$ event. At the regional scale, these continental results seem consistent with the Adriatic climate data from northwestern Greece to the Po Valley in northern Italy. The confrontation with the nearest multi-proxy marine records (MD 90-917 in the central Adriatic sea) and northern Aegean Sea consolidates the regional climate-environmental mechanisms previously described (Rohling et al., 2002; Khotthoff et al., 2008; Combourieu-Nebout et al., 2013; Berger et al., 2014) (Figs. 2, 12a). The pollen of deciduous oak forests (reflecting tree-covered peri-Adriatic mountains) sharply decreases to each rapid hydromorphological change observed in Sidari, in synchrony with the RCC, around 10.1, 9.2 and $8.3 \mathrm{ka}$ (Combourieu-Nebout et al., 2013). This functioning coincides with the dominance of coniferous forest (mainly firs) at high altitudes at ca. 8.5-7.8 ka (lakes Ribno and Trilistnika, southwestern Bulgaria) (Tonkov et al., 2013) and with the replacement of Quercus-dominated forests with mixed deciduous forests at around $8.3 \mathrm{ka}$. These regional evolutions underline the role of climate change and cooling more than the consequences of the onset of agropastoral activities during this period.

Nevertheless, the observations made on the edge of the Tenaghi Philippon marsh evoke questions. In fact, from 8.4 to $8.1 \mathrm{ka}$, a general cooling has been recorded by recent Holocene palaeoclimatic studies in the Tenaghi Philippon marsh (Pross et al., 2009) and northern marine Aegean region (Kotthoff et al., 2008) with an interruption in Sapropel 1 formation (Fig. 2). These studies propose a scenario of deteriorated winter climate conditions with temperatures lowered by more than $4{ }^{\circ} \mathrm{C}$ in winter, less than $2{ }^{\circ} \mathrm{C}$ in summer (Pross et al., 2009). Sea surface temperature from the core MD 90917 in the central Adriatic Sea (Fig. 2) also indicates a decrease of at least $2{ }^{\circ} \mathrm{C}$ between 8.3 and $8.1 \mathrm{ka}$ (CombourieuNebout et al., 2013). Davies et al. (2003) identified a strong decrease in summer temperatures at the same time at the scale of southern Europe (8.3-7.8 ka). This is explained by an increase in outbreaks of cold and dry air from higher latitudes (SH) (Rohling et al., 2002; Marrino et al., 2009). The climate was drier and characterised by a decrease of annual rainfall by $800-600 \mathrm{~mm}$ due mainly to a decrease of winter precipitation. The apparent contradiction between (i) the local pollen and geomorphological data and (ii) the regional climate reconstruction from pollen data, we suggest that the cooling was favourable to the development of snow cover and associated spring-flood flows and to reduction in evapotranspiration (Lespez et al., 2013) or that Tenaghi Philippon sampling is not precise enough to describe the internal structure and moister episodes of the $8.2 \mathrm{ka}$ event. Moreover, it appears that the summer rains increased during this period (Peyron et al., 2011), limiting summer evapotranspiration and probably the decrease of the water table as observed for late Quaternary cold periods in Anatolia, for example (Jones et al., 2007). Thus, local water balance can be different to the regional trend, which is, moreover, not indicative of the flood flow energy and frequency. It appears that cold air SH extension mixed with the warmer air over the Mediterranean may have created a surplus of potential energy resulting in regional cyclogenesis (Makorgiannis et al., 1981) from spring to autumn, triggering significant flood flows in the studied areas. An increase in climatic instability and summer rains may explain the hydrogeomorphological signals of the Sidari 1 and 2 valleys. The repeated succession of gullies and torrential discharges between 8.4 and 7.9 ka (Figs. 11a, c, d, 12a) could be associated with concentrated summer rains and increase in climatic instability. An increase in southerly winds (D-enriched moisture) with a strong Mediterranean component

\subsection{The potential impact of the $8.2 \mathrm{ka}$ event on societies}

\subsubsection{An impact primarily focused on readability of archaeological archives}

We know almost nothing of the late Mesolithic (blade and trapeze assemblages) in the Balkan Peninsula (7th millennia BC). Our new data will not, however, solve this problem. Only very restricted regions like the Iron Gates are documented, but these are far from the Aegean coast. A similar observation seems true in western Turkey (Özdogan, 2007). The hiatus seems to be partly bridged by systematic surveys such as in the mountains of Pindus between Macedonia and Epirus (Efstratiou et al., 2006), or by geoarchaeological explorations further in floodplains and the vast sedimentary basins of the Aegean and Balkan (Berger, 2016). Our data show that the $8.2 \mathrm{ka}$ event played a significant role in the archaeological records. Indeed, truncature and hiatuses correspond to erosional events or riverscape changes more than abandonment of inhabited areas. This explains, for example, the archeological continuity which led the first archaeologists of the site to suggest the hypothesis of a "Sidarian" Neolithic inherited from an existing local Mesolithic. Alluvial truncations moved sedimentary horizons of these two cultural periods (by sediment ablation) and may even have connected them within alluvial formations where we found reworked Mesolithic and early Neolithic material and charcoal (Berger et al., 2014). New data and reinterpretation of old archaeological data illustrate a strong erosion phase at the 
Mesolithic-early Neolithic transition in the central Mediterranean area (Mlekuz et al., 2008; Berger and Guilaine, 2009; Berger et al., 2014). A similar process is observed in the eastern Mediterranean area in the Khirokitia sites (Cyprus), where at least two episodes of fluvial discharges, flash flood types, strongly impact the Neolithic village. The same dynamic is observed in Ain Ghazal, Wadi Shu'eib and Abu Thawwab in the Levant, where densely packed layers of cobble deposits are observed between late PPNB and PN archaeological horizons (Simmons and Mandel, 1988), with a permanent uncertainty about the absolute chronology of these events after the remobilisation of ${ }^{14} \mathrm{C}$-dated old bones (Zielhoffer et al., 2012). Even in protected contexts such as western Albanian mountain caves in front of Corfu, geoarchaeological studies identified a long slope instability period responsible for a partial erosion of the archaeological deposits (8.2 ka event effects?) (Schuldenrein, 1998) (Figs. 7a, 13) synchronous of Sidari valley geomorphic changes. In some floodplains, even if the fluvial activity did not imply a highenergy event, as in Dikili Tash, the increase of water level may change the location of the inhabited areas. There, the vegetation cover and hydrosedimentary changes were the result of change in climatic conditions and the development of anthropisation. The marshy and fluvial sedimentation interrupts the archaeological sedimentation on $\mathrm{C} 3$ and $\mathrm{C} 2$ and reaches 53-54 m above sea level. However, C10 and C1, located slightly higher on the former alluvial fan, $54 \mathrm{~m}$ above sea level, show the continuation of the settlement during the $8.15-7.8$ ka period (Figs. 10, 12). Therefore, it is noticeable that the climatic change and its geomorphological consequences do not infer a notable hiatus in human occupation but probably merely a local displacement and relocation of the settlement on the tell (Lespez et al., 2013, 2016). At the same time, deep explorations of Macedonian floodplains attest to the presence of Neolithic levels under several metres of alluvial sediments (Lespez et al., 2014), which raises questions about the extent of the still-hidden archaeological reserve. In this context, the middle Neolithic lakeside site of Dispilio (Thessaly) offers a strong potential for future research about mid-Holocene palaeohydrological changes in northern Greece (Karkannas et al., 2011; Kouli and Dermitzakis, 2008). Such new documentation will concern the relationships between environmental fluctuations and the end of the Neolithic of the region. Obviously, the few examples discussed clearly illustrate that $8.2 \mathrm{ka}$ event geomorphological evolution plays a major role in the distortion of the first Neolithic signal, in the NE to central Mediterranean zone where Neolithisation occurs and advances just before the 8.2. event. The strong rainfall irregularity that seems to characterise the period around the $8.2 \mathrm{ka}$ event could be the cause of these repeated impacts on Neolithic river sites (Fig. 13). The greatest contribution of the summer rains (Peyron et al., 2013) may be an explanation for the observed hydrogeomorphological functioning between Cyprus and the Balkans and the difficulty of linking environmental changes and settlement history as in the three sites mentioned. Postdepositional processes from anthropogenic origin are difficult to assess. Excavations in caves and rock shelter sites in the Tristine karst and in Istria also record a temporal gap between the latest Mesolithic and the earliest Neolithic occupations (Mlekuz, 2005; Forenbaher and Miracle, 2005). However, in a context where inversions in radiocarbon dates occur and where Castelnovian microliths "pollute" Neolithic deposits, the gap could be caused by insufficient radiocarbon evidence, occurrence of erosional surfaces due to anthropogenic action, and sedimentary hiatuses (Mlekuz et al., 2008).

\subsubsection{The Neolithic spreading westward through Anatolia?}

The question that now arises is, in the case of western Anatolia, why and how the diffusion of Neolithic practices occurred from the central plateaus towards the Aegean region, and at what speed. The early Neolithic is rooted in local PPN cultures at Catalhöyük East ca. 9.4/9.3 ka cal BP, in the Lake District ca. 9.2/9.1 ka cal BP, and possibly in the Aegean region (Ulucak) in the early centuries of the 9th millenium cal BP (Fig. 14). In these specifically local contexts, pottery appears at about the same time in excavated sites between 9.0 and $8.8 \mathrm{ka} \mathrm{cal} \mathrm{BP}$.

From 8.6 to $8.0 \mathrm{ka}$, the cultures of Yarmoukian (southern Levant), Khirokitian (Cyprus), and Monochrome (western Anatolia, Aegean) (Fig. 2) are directly faced with climate change. There is also manifold evidence for population movements in coastal and low-lying locations in the northern and southern Levant, and finally with the abrupt appearance of Neolithic communities in the Aegean/Ionian zone, where Dikili Tash and Sidari are located (Weninger et al., 2014). Weninger et al. $(2006,2014)$ suggest that climateinduced crises may have forced early farming communities to break up and move in order to escape new conditions and possible related conflicts (scalar stress). In the first phase of the $8.2 \mathrm{RCC}(8.6-8.3 \mathrm{ka}$ : phase A), there is evidence of a push/pull to coastal and lower-lying locations in the southern Levant and Anatolia after Clare (2013), but this trend hypothesis seems questionable according to Flohr et al. (2016) and from the anatolian data discussed in this paper. As coastal and lower-lying areas would have been less affected by typical RCC impacts (drought and severe winters) (Weninger et al., 2014), the related abandonment of sites in Jordan, in the northern Levant, eastern Anatolia and Cyprus is referred to as the "late Yarmoukian crisis". This cultural event coincides for the authors with a further wave of Neolithic expansion into southeastern Europe in the second phase of RCC (8.3-8.0 ka: phase B). But in the light of three new radiocarbon data series (with charcoals and shortlived species) on the early Neolithic from northern Greece and of new, clear geoarchaeological contexts, we propose a different temporal timing for northern Greece colonisa- 
Konispol cave, Albania (after Schuldenrein et al. 1998)

Sidari 1, Corfu (after Berger et al. 2014)
Dikili Tash, Macedonia-C3 (after Lespez et al. 2013)
Khirokitia-Maroni valley

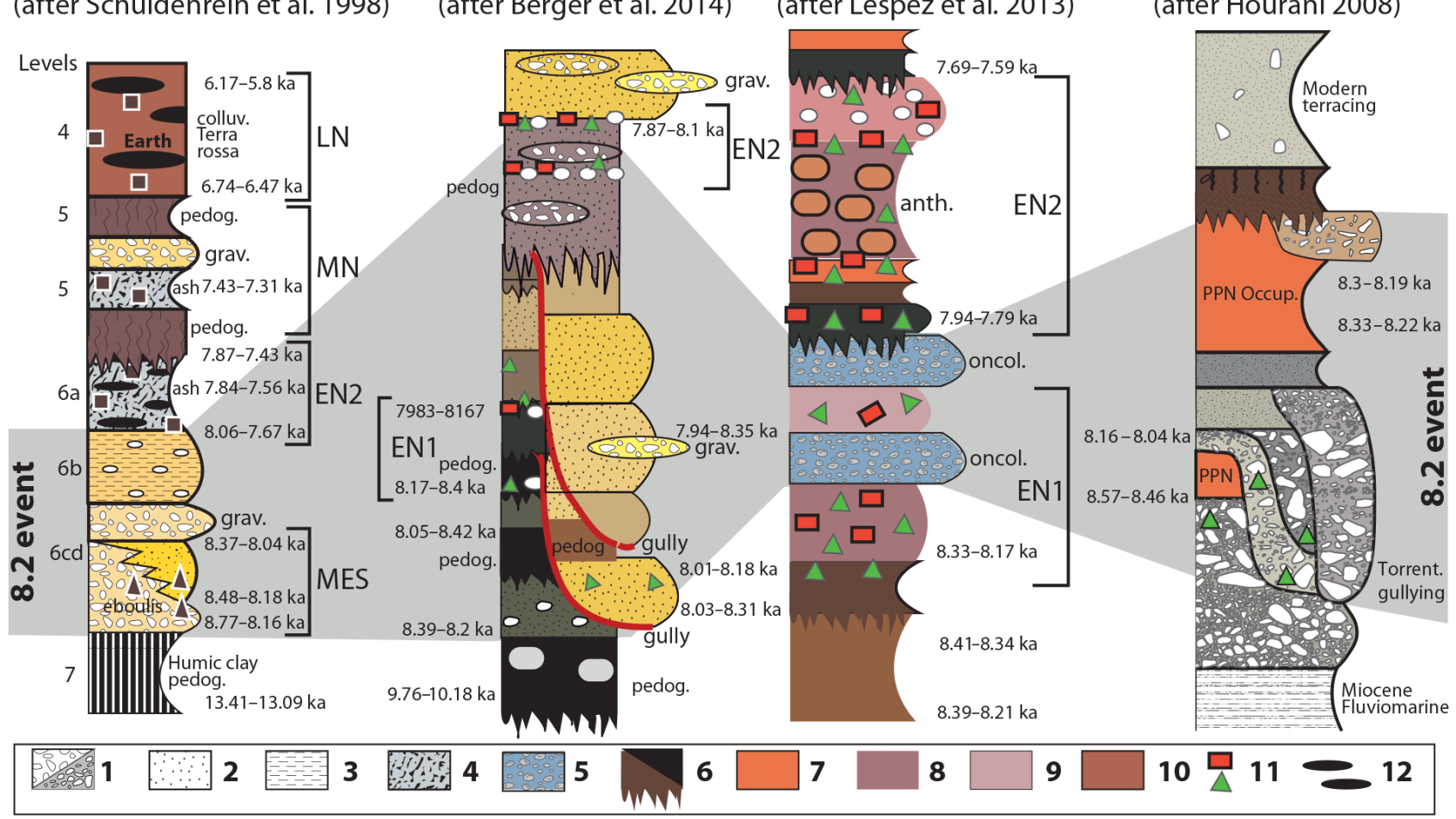

Figure 13. Morpho- and pedosedimentary contexts of four central to eastern Mediterranean early Neolithic sites (Konispol Cave, Sidari, Dikili Tash and Khirokitia) illustrating the $8.2 \mathrm{ka}$ event effects on the archaeological occupations. Geomorphological change applies on pure anthropogenic horizons or palaeosols, revealing an abrupt change in the local pedosedimentary functioning: 1, gravel layer; 2 , sandy layer; 3, silty layer; 4, ashy layer; 5, oncolithic sands; 6, palaeosols; 7, in situ Neolithic layers; 8, slightly reworked Neolithic layer; 9, strongly reworked Neolithic layer; 10, red silty clay colluvial deposit (from Terra Rossa); 11, flints/ceramics; 12, earth radiocarbon dates are in ka cal BP.

tion than Weninger et al. (2014) by demonstrating the anteriority of Neolithic migration from western Anatolia (Dikili Tash, Sidari, Mavropigi-Filotsairi and Nea Nikomedia) to the second phase (B) of $8.2 \mathrm{ka}$ events, sometimes far to the west. This assertion is also based on local chronostratigraphic and geomorphic contexts in Sidari and Dikili Tash, which illustrate the posteriority of hydrogeomorphological and erosion signatures to Neolithic implantations (Figs. 12a, 13). The chronology of this northern Greece Neolithic package implantation would no longer be synchronous with the strictly speaking $8.2 \mathrm{ka}$ event (glacial-outburst-derived effects), whose minimum time is estimated between 8.2 and $8.05 \mathrm{ka}$ in the more precise glacial and speleothem proxy data (Fig. 1) but could be in adequation with the more general aridification/cooling from 8.6/8.5 to $8.0 \mathrm{ka}$ (Rohling and Pälike, 2005; Göktürk et al., 2011). The earliest spread of Neolithic packages to western and northwestern Anatolia occurred almost a thousand years before the $8.2 \mathrm{ka}$ event, as illustrated by recently published robust chronological studies (Özdogan et al., 2012a, b; Düring 2013; Clare, 2013; Brami, 2014; Kuzucuoglu, 2014; Stiner et al., 2014; Weninger et al., 2014; Flohr et al., 2016) (Figs. 12a, 14). The question that now arises is whether the diffusion of Neolithic prac- tices which began in the central Anatolian highlands around $8.7 \mathrm{ka}$ are included in the same timing and in a same cultural stream, the northern Aegean area to the southern Balkan borders (Thrace, Macedonia, Thessaly). This hypothesis is defended by Weninger et al. (2014), who claim that, from the middle of phase A (Figs. 1, 12b), a rapid and continuous colonisation movement can fit from the highlands of central Anatolia to Greece, with a median speed to the Neolithic wave of advance from 4 to $6 \mathrm{~km} \mathrm{yr}^{-1}$. We should not forget that, in the general Neolithic mobility trend from Anatolia, Franchthi Cave (Argolid) was occupied by farmers around $8.6 \mathrm{ka}$ (new dates on seeds) (Perlès et al., 2013), not much later than the earliest occupation of Knossos in Crete (Efstratiou et al., 2004). These data evidence clearly the existence of a southern route, and support a multiple-origin model for the introduction of the Neolithic in Europe. It is, however, still necessary to evidence short-lived hemisphere-scaled aridification events (short droughts?) in marine and terrestrial climate records, which would coincide with the supposed $\mathrm{Ne}$ olithic population movement from central Anatolia. This evidence could be provided by CPDF treatments such as those proposed by Flohr et al. (2015), which enlightens the starting of a climatic aridification at least ca. $8.7 \mathrm{ka}$ cal BP. How- 


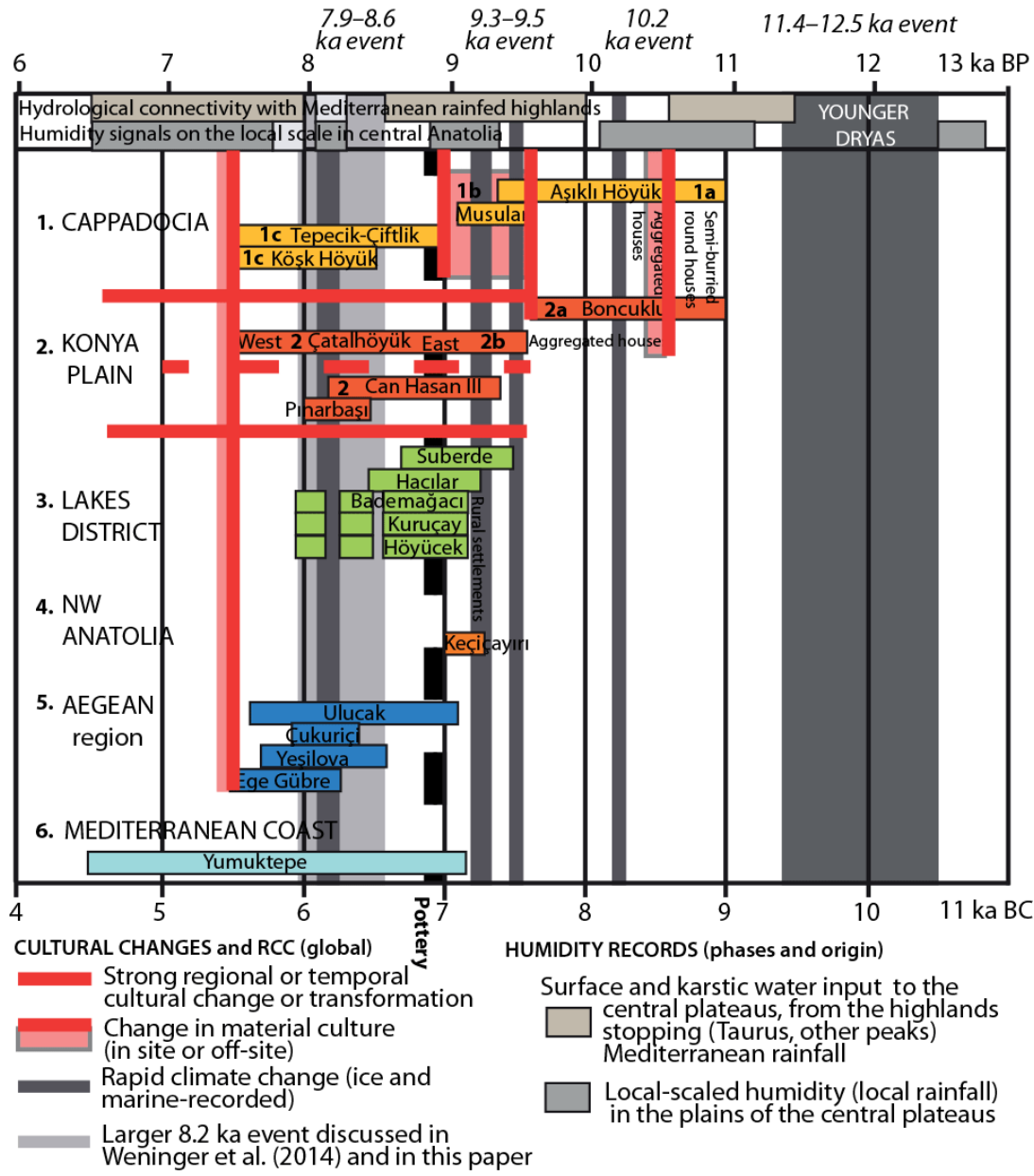

Figure 14. Neolithic dynamic and early Holocene RCC in Anatolia. Note: sites are selected on the basis of being the oldest ones excavated in their region (i.e. sites founded after $8.0 \mathrm{kacal} \mathrm{BP}$ are not shown) (sources: Fontugne et al., 1999; Kuzucuoğlu et al., 1997, 1998, 1999; Düring, 2002, 2011; Boyer et al., 2006; Gürel and Lermi, 2010; Özbaşaran, 2011; Baird, 2012; several articles in Özdoğan et al., 2012a, b; Kuzucuoğlu, 2013, 2014; Stiner et al., 2014).

ever, the overview of the current multi-proxy data identifies a real general trend from 8.6 to $8.5 \mathrm{ka}$ (Fig. 12b), and real continental hydrogeomorphological evolutions seem to occur only from $8.4 \mathrm{ka}$ (Fig. 13). Can this lag be attributed to the age models used in the environmental series? The reservoir effects cannot be challenged here since western Anatolia chronocultural series are based on a robust set of shortlived dates. Furthermore, the results obtained in central Anatolia underline the contrasted response, in time and in space, of the local environment to RCC (Fig. 14). Alluvial fans of the Taurus piemonts stops to aggrade from $8.5 \mathrm{ka}$ to 8.0 and palaeosols are recorded between 8.2/8.1 and 8.0/7.9 ka, illustrating a drier period which seems to have begun earlier in other central Anatolian highlands (Bor Plain, Tuz Gölü, Akgöl marsh) around $8.9 \mathrm{ka}$, and, in the Bor Plain, a humid period is recorded from 8.5 to $8.1 \mathrm{ka}$, before a fast, sharp drop in the aquifer. The hypothesis of a trigger that is foremost cultural will also be considered; the ball is now in the culturalists' court.

The second "European" step took Neolithic lifestyles away from the Aegean coastline all the way to continental Bulgaria and Serbia by the main river axis (Struma, Vardar, Maritsa) and could be associated with the Düljunica (Raiko Krauß et al., 2014), Anzabegovo (Gimbutas, 1976) and Kovacevo (Lichardus-Itten, 2016) pre-Karanovo sites just after the Hudson Bay event (around $8.1 \mathrm{ka}$ ), i.e. almost 200/250 years after the first European Neolithic wave. We must now integrate into the coming socio-environmental discussions on the steps of the Neolithic diffusion through the Balkans and the Adriatic a last shudder of $8.2 \mathrm{ka}$ event between 8.05 and $7.9 \mathrm{ka}$ (Fig. 1 - green, i.e Lake Maliq, Qunf Cave, Sofular, Steregiou, marine core SL 21, Sidari). This episode is clearly in step with a peak in $[\mathrm{K}+]$ on GISP2 and a small bond event. We enter here in a temporality of the $8.2 \mathrm{ka}$ event that was little discussed, that of a possible 
tripartitioning of the event we are trying to argue based on Sidari (Berger et al., 2016) and Dikili Tash records. A twostage cooling around the time of the $8.2 \mathrm{ka}$ event has been identified in speleothems of Ireland (Baldini et al., 2002), in pollen diagrams from central Europe (Lotter and Tinner, 2001), and in lacustrine records in Norway (Nesje and Dahl, 2001), and a two-step release of Lake Agassiz waters has been modelled by Clarke et al. (2004). The marine data of LC 21, SL21E and MD952043 also show two colder peaks separated by a temperate rise, while Dongge Cave $\delta^{18} \mathrm{O}$ (Wang et al., 2005) and Qunf Cave isotopic data illustrate two hyperarid episodes separated by a wetter episode. More recently, observed changes in $\Delta \mathrm{D}$ wax from Tenaghi Philippon during two isotope events reflect changes in $\triangle \mathrm{D}$ of precipitation during the $8.2 \mathrm{ka} \mathrm{BP}$ climatic event according to a close tempo. They are interpreted as primarily caused by changes in the relative contributions of different air masses to local precipitation (higher amounts of precipitation originating in the Mediterranean sea) (Schemmel et al., 2016). We find here the most complex structure of the $8.2 \mathrm{ka}$ event discussed by Thomas et al. (2007) based on isotopic data of GISP2 and GRIP. We must now integrate this new climatic and environmental temporality into the classical Neolithic wave of advance hypothesis, if they are linked. The challenge is open.

\subsubsection{Climatic event and social impact}

More fundamentally, the impacts of climatic changes or natural extreme events have to be evaluated in terms of biophysical and social vulnerabilities. Burton et al. (1993, p. 35) refer to the seven dimensions of hazardous events: magnitude, frequency, duration, speed of onset, geographical extent, spatial dispersion, and temporal spacing. However, as underlined by Clare and Weninger (2008), impacts upon the resources of a society are primordial (availability of natural resources), and responses in terms of resources addressed (variety), land use (management), technology (tool production, equipment progress, variety), housing quality and residence location adaptability have to be considered. Social vulnerability studies must consider the societal perception of the causes of environmental change (Blaikie et al., 1994) and the efficiency of social communication processing (Van der Leeuw et al., 2009). There is also a need for more sitespecific detailed studies focusing on ecological bases and strategies (Flohr et al., 2016). Only such new trajectories, closely interlinked with the intra-archaeological sites' multidisciplinary analyses, will optimise our perception of forms of socio-environmental resilience. Concretely, for the period and the studied areas, the abrupt global cold events might have affected the vegetative season time, growth of wild plants and predictability of food resources. Loss of soil cover potential (by erosion), as well as the effects of dryness or wetness on soil productivity, can be directly or indirectly documented by quantitative climate reconstructions from pollen diagrams (Peyron et al., 2011). Such data allow discussions about agrarian constraints during RCC events. Recent fire signal studies in the eastern Mediterranean (Lake Van in Wick et al., 2003; Dikili Tash, this study; Sidari, in progress) document dryness, fuel availability and variations in vegetation cover. Similar studies, if systematized in the future, will allow for better evaluation of the respective roles and links of climate changes and human impacts on vegetation. Nevertheless, we must keep in mind that the geographical setting of the eastern Mediterranean results in physically very contrasting environments in which it is often sufficient to move over very short distances to find different environmental conditions (Willcox, 2005; Lespez et al., 2016). In fact, a dry period could imply a move closer to water resources or, conversely, as observed in Dikili Tash, a rise of water table and flood hazards might imply leaving the floodplain to settle higher on the alluvial fans or lower slopes in the surrounding areas. The uneven exploratory and excavation practices on sites and around sites are to question: the lack of extensive archaeological excavations on most reference Neolithic sites (and our uncomplete knowledge of the other ones too, information that is crudely lacking when discussing occupation dates and periods) strongly hampers interpretations on the continuity of Neolithic occupations and therefore and does not always decide on climate impacts on societies. Furthermore, Neolithic communities rely on diverse subsistence strategies including wild resources (Asouti and Fuller, 2013) even during more recent periods (Valamoti, 2015). Finally, the resilience of the early farming societies should not be underestimated (Flohr et al., 2016).

\section{Conclusions}

Our paper discusses examples from river and lake systems, from the eastern to central Mediterranean areas (central Anatolia, Cyprus, northeastern and northwestern Greece), which represent continental archives where early Holocene RCC events and their local impact on prehistoric societies can be or is recorded. This study demonstrates the reality of hydrogeomorphological responses to early Holocene RCCs derived from glacial outburst in valleys and alluvial fans and lake-marsh systems. It highlights the importance of Holocene sedimentation and post-depositional disturbances in reading the Mesolithic-early Neolithic transition and attestation of the first true levels of Neolithic occupation in southeastern Europe. Terrestrial records still reflect heterogeneities in palaeoclimatic restitution across the northeastern Mediterranean during RCC events (from central Anatolia to the southern Balkans). This signal heterogeneity will now be discussed in terms of quality of exploited archives, of sampling/measuring time resolution and of regional climatic pattern variations. The widespread use of core scanner geochemical analysis will promote the identification of the finest Holocene variations. The issues are important to better assess climate impact on the functioning of coastal 
and continental environments, in major societal disruptions such as the Neolithisation of the Mediterranean. Research on the effects and impacts of 10.2 and $9.2 \mathrm{ka}$ RCCs is still in its infancy. Not only are RCC records potentially present in continental sedimentary archives but both their signals and their possible impacts should be better evaluated in the light of socio-environmental perspectives. The probable tripartitioned timing of the 9.2 and $8.2 \mathrm{ka}$ events complicates our view of the Neolithic development and colonisation of Europe. Our hypothesis of an early Neolithic colonisation of the northern Aegean (around $8.4 \mathrm{ka}$ ), prior to the assertion of the second and more marked part of the $8.2 \mathrm{ka} \mathrm{RCC}$ event, should be supported by new data in the coming years thanks to the increasing number of deep trenches and core drilling in regional river and marshy areas, including the immediate vicinity of the main Neolithic tells whose first sedimentary archives are still often unknown (Fig. 12). The simultaneous achievement of pollen studies with very high time resolution will complete the approach to attest to the first early agricultural practices. These data must be compared to precise archaeological data in order to assess the impact of the climatic changes on the environment and the farming societies at the local scale. Rather than collecting radiocarbon dates in order to propose modelisation of Neolithic expansion, we need to have more case studies at the regional and eastern Mediterranean scale if we want to discuss reasonably the role of climatic changes in cultural transformation. Archaeological data still hidden under alluvium hinder our understanding of land use and historical dynamics, leaving many surprises still to be found.

\section{Information about the supplement}

Radiocarbon dates of Sidari and Khirokitia sites and Dikili Tash cores.

\section{The Supplement related to this article is available online at doi:10.5194/cp-12-1847-2016-supplement.}

Acknowledgements. We thank Paléomex-ArcheoMed (CNRS INEE) for their financial and logistic support. This paper has benefited from the financial support from the ENVOL programme of the MISTRALs project. Many thanks to the French missions of the foreign office (MAE) in Greece (site of Dikili Tash; P. Darcque, and Z. Tsirtsoni) and in Cyprus (site of Khirokitia; A. Le Brun). We are also grateful to the Collège de France, "chaire des Civilisations de l'Europe au Néolithique et à l'âge du Bronze" and the 8th Ephorate of Prehistoric and Classical Antiquities, Corfu (G. Metallinou). We finally thank the Laboratoire de Mesure du Carbone 14, UMS 2572, and ARTEMIS in Saclay for ${ }^{14} \mathrm{C}$ measurements by SMA in the frame of the national service to CEA, CNRS, IRD, IRSN and Ministère de la Culture et de la Communication. Support from the Aşıklı Höyük, Tepecik-Ciftlik and Kınık Höyük excavations in Cappadocia and from geological teams in MTA (Ankara) and in Niğde University, as well as scientific discussions with Profs. M. Ösbaşaran, M. Özdoğan, E. Bıçakçı and M. Godon, is deeply acknowledged.

Edited by: M.-F. Loutre

Reviewed by: B. Paolo and one anonymous referee

\section{References}

Akkermans, P. M. M. G., Brüning, M., Huigens, H., and Nieuwenhuyse, O. P. (Eds.): Excavations at Late Neolithic Tell Sabi Abyad, Syria, The 1994-1999 Field Seasons, Brepols, Turnhout, 2014.

Alley, R. B., Mayewski, P. A., Sowers, T., Stuiver, M., Taylor, K. C., and Clark, P. U.: Holocene climatic instability - a prominent, widespread event 8200 yr ago, Geology, 25, 483-486, 1997.

Asouti, E. and Fuller, D. Q.: From foraging to farming in the southern Levant: The development of Epipalaeolithic and Pre-Pottery Neolithic plant management strategies, Veg. His. Archaeobot., 21, 149-162, 2012.

Asouti, E. and Fuller, D. Q.: A contextual approach to the emergence of agriculture in Southwest Asia, Curr. Anthropol., 54, 299-345, 2013.

Baird, D.: The Late Epipaleolithic, Neolithic and Chalcolithic of the Anatolian Plateau, $13000-4000$ BC, in: A Companion to the Archaeology of the Ancient Near East, edited by: Potts, D., WileyBlackwell, Oxford, 431-465, 2012.

Baldini, J. U., McDermott, F., and Fairchild, I. J.: Structure of the 8200 -year cold event revealed by a speleothem trace element record, Science, 296, 2203-2206, 2002.

Bar-Matthews, M., Ayalon, A., and Kaufman, A: Late Quaternary paleoclimate in the eastern Mediterranean region from stable isotope analysis of speleothems at Soreq Cave, Israel, Quaternary Res., 47, 155-168, 1997.

Bar-Matthews, M., Ayalon, A., Gilmour, M., Matthews, A., and Hawkesworth, C. J.: Sea-land oxygen isotopic relationships from planktonic foraminifera and speleothems in the Eastern Mediterranean region and their implication for paleorainfall during interglacial intervals, Geochim. Cosmochim. Ac., 67, 31813199, 2003.

Bar-Yosef, O. and Belfer-Cohen, A.: The origins of sedentism and farming communities in the Levant, J. World Prehist., 3, 447498, 1989.

Benito, G., Macklin, M. G., Zielhofer, C., Jones, A. F., and Machado, M. J.: Holocene flooding and climate change in the Mediterranean, Catena, 130, 13-33, 2015.

Berger, J.-F.: Sédiments, dynamique du peuplement et climat au Néolithique ancien, in: Populations néolithiques et environnements, edited by: Guilaine, J., Errance, Paris, 155-212, 2006.

Berger, J.-F.: Approche socio-environnementale du Néolithique à l'Anthropocène: quelques études intégrées de la vallée du Rhône aux milieux nord Méditerranéens, Habilitation à Diriger des Recherches, Spécialité: Géographie physique, Université Lyon 2, 780 pp., 2015.

Berger, J.-F.: Quand le front néolithique passait par Dikili Tash et Kovačevo: une vision géoarchéologique et des hypothèses en débat sur la néolithisation des Balkans méridionaux 
! In Manolakakis, Coudart, Schlanker (Dir.), Archéologie européenne: identités et Migrations, Hommages à Jean-Paul Demoule, Sidestone Press, in press, 2016.

Berger, J.-F. and Guilaine, J.: 8200 cal BP abrupt environmental change and the Neolithic transition: A Mediterranean perspective, Quaternary Int., 200, 31-49, 2009.

Berger, J. F., Delhon, C., Magnin, F., Bonté, S. Peyric, D., Thiébault, S., Guilbert, R., and Beeching, A.: A fluvial record of the MidHolocene Rapid Climatic Changes in the Middle Rhone Valley (Espeluche-Lalo, France) and of their impact on Late Mesolithic and Early Neolithic populations, Quaternary Sci. Rev., 136, 6684, 2016.

Biagi, P. The Last Hunter-Gatherers of the Northern Coast of the Black Sea and their Role in the Mesolithic of Europe, in: Southeast Europe before Neolithisation, edited by: Krauss, R. and Floss, H., 2016.

Blaikie, P., Cannon, T., Davis, I., and Wisner, B.: At Risk. Natural Hazards, people's vulnerability, and disasters, Routledge, London and New York, 1994.

Bocquet-appel, J.-P., Dubouloz, J., Moussa, R., Berger, J.-F., Tresset, A., Ortu, E., Vigne, J.D., Bendrey, R., Brehard, S., Schwartz, D., Salavert, A., Sanchez-Goni, M.F., Ertlen, D., Gauvry, Y., Davtian, G., Vander Linden, M., Leneis, E., Guillaumont, A., and O'Connor, M.: Multi-agent modelling of the trajectory of the LBK Neolithic: a study in progress, Early Farmers: the View from Archaeology and Science, in: Proceedings of the British Academy, Vol. 198, edited by: Whittle, A. and Bickle, P., 2014.

Bordon, A., Peyron, O., Lézine, A. M., Brewer, S., and Fouache, E.: Pollen-inferred late-glacial and Holocene climate in southern Balkans (Lake Maliq), Quaternary Int., 200, 19-30, 2009.

Bonsall, C.: When was the Neolithic transition in the Iron Gates, A Short Walk through the Balkans: the First Farmers of the Carpathian Basin and Adjacent Regions, Quaderno, 12, 53-68, 2007.

Borrell, F.: From PPNB to PN: Chipped Stone Industries of the Middle Euphrates Valley, New Data, New Interpretations, NeoLithics ex orientee, 1/07, 33-36, 2007.

Borrell, F., Junno, A., and Barceló, J. A.: Synchronous Environmental and Cultural Change in the Emergence of Agricultural Economies 10,000 Years Ago in the Levant, PloS one, 10, e0134810, doi:10.1371/journal.pone.0134810, 2015.

Bottema S. and Woldring H.: Late Quaternary vegetation and climate of southwestern Turkey II, Palaeohistoria, 26, 123-149, 1984.

Boyer P., Roberts N., and Baird D.: Holocene environment and settlement on the Carsamba alluvial fan, south-central Turkey: Integrating geoarchaeology and archaeological field survey, Geoarchaeology, 21, 675-698, 2006.

Brami, M. N.: A graphical simulation of the 2,000-year lag in Neolithic occupation between Central Anatolia and the Aegean basin, Archaeol. Anthropol. Sci., 7, 319-327, 2014.

Brayshaw, D. J., Rambeau, C. M., and Smith, S. J.: Changes in Mediterranean climate during the Holocene: Insights from global and regional climate modelling, The Holocene, 21, 15-31, 2011.

Budja, M.: The $8200 \mathrm{cal} \mathrm{BP}$ 'climate event'and the process of Neolithisation in southeastern Europe, Documenta Praehistorica, 34, 191-201, 2007.

Burton, I., Kates, R. W., and White, G. F.: The Environment as Hazard, The Guilford Press, New York, 1993.
Cauvin, J.: The symbolic foundations of the Neolithic Revolution in the Near East, in: Life in Neolithic farming communities, Springer US, 235-252, 2002.

Clare, L.: Culture Change and Continuity in the Eastern Mediterranean and During Rapid Climate Change. Assessing the Vulnerability of Neolithic Communities to a Little Ice Age in the Seventh Millennium calBC, unpublished $\mathrm{PhD}$ thesis, University of Cologne, Cologne, 2013.

Clare, L, Rohling, E., Weninger, B., and Hilpert, J.: Warfare in Late Neolithic/Early Chalcolithic Pisidia, Southwestern Anatolia, in: Climate induced social unrest in the late 7th millennium calBC, edited by: Budja, M., 15th Neolithic Studies, Documenta Praehistorica, 35, 65-92, 2008.

Clare, L. and Weninger, B.: Social and Biophysical Vulnerability of Prehistoric Societies to Rapid Climate Change, Documenta Praehistorica, 37, 283-292, 2010.

Cohen-Seffera, R., Greenbaum, N., Sivan, D., Jull, T., Barmeir, E., Croitoru, S., and Inbar, M.: Late Pleistocene-Holocene marsh episodes along the Carmel coast, Israel, Quaternary Int., 140, 103-120, 2005.

Combourieu-Nebout, N., Peyron, O., Bout-Roumazeilles, V., Goring, S., Dormoy, I., Joannin, S., Sadori, L., Siani, G., and Magny, M.: Holocene vegetation and climate changes in the central Mediterranean inferred from a high-resolution marine pollen record (Adriatic Sea), Clim. Past, 9, 2023-2042, doi:10.5194/cp9-2023-2013, 2013.

Cullen, H. M., Hemming, S., Hemming, G., Brown, F. H., Guilderson, T., and Sirocko, F.: Climate change and the collapse of the Akkadian empire: evidence from the deep sea, Geology, 28, 379382, 2000.

d'Alfonso, L., Balza, M. E., and Mora, C.: Geo-archaeological activities in southern Cappadocia, Turkey. Proceedings of the Meeting held in Pavia 20 November 2008, Italian Univ. Press, Pavia, 140 pp., 2010.

Davis, S. J.: The zooarchaeology of Khirokitia (Neolithic Cyprus), including a view from the mainland, Supplément au Bulletin de correspondance hellenique, 253-268, 2003.

Davis, B. A., Brewer, S., Stevenson, A. C., and Guiot, J.: The temperature of Europe during the Holocene reconstructed from pollen data, Quaternary Sci. Rev., 22, 1701-1716, 2003.

Dean, J. R., Jones, M. D., Leng, M. J., Noble, S. R., Metcalfe, S. E., Sloane, H. J., Sahy, D., Eastwood, W. J., and Roberts, C. N.: Eastern Mediterranean hydroclimate over the late glacial and Holocene, reconstructed from the sediments of Nar lake, central Turkey, using stable isotopes and carbonate mineralogy, Quaternary Sci. Rev., 124, 162-174, 2015.

Desprat, S., Combourieu-Nebout, N., Essallami, L., Sicre, M. A., Dormoy, I., Peyron, O., Siani, G., Bout Roumazeilles, V., and Turon, J. L.: Deglacial and Holocene vegetation and climatic changes in the southern Central Mediterranean from a direct land-sea correlation, Clim. Past, 9, 767-787, doi:10.5194/cp-9767-2013, 2013.

Düring, B. S.: Cultural dynamics of the Central Anatolian Neolithic: The Early Ceramic Neolithic - Late Ceramic Neolithic transition, in: The Neolithic of Central Anatolia: Internal Developments and External Relations during the 9th-6th Millennia cal BC, edited by: Gérard, F. and Thissen, I. , Ege Yayinlari, Istanbul, 219-236, 2002. 
Düring, B. S.: The Prehistory of Asia Minor. From Complex Hunter-Gatherers to Early Urban Societies, Cambridge University Press, 360 pp., 2011.

Düring, B.S.: Breaking the Bond: Investigating the Neolithic Expansion in Asia Minor in the Seventh Millennium BC, J. World Prehist., 26, 75-100, 2013.

Dykoski, C. A., Edwards, R. L., Cheng, H., Yuan, D., Cai, Y., Zhang, M., and Revenaugh, J.: A high-resolution, absolute-dated Holocene and deglacial Asian monsoon record from Dongge Cave, China, Earth Planet. Sc. Lett., 233, 71-86, 2005.

Eastwood, W. J., Roberts, N., Lamb, H. F., and Tibby, J. C.: Holocene environmental change in southwest Turkey: a palaeoecological record of lake and catchment-related changes, Quaternary Sci. Rev., 18, 671-695, 1999.

Eastwood, W. J., Leng, M. J., Roberts, N., and Davis, B.: Holocene climate change in the eastern Mediterranean region: a comparison of stable isotope and pollen data from Lake Gölhisar, southwest Turkey, J. Quaternary Sci., 22, 327-341, 2007.

Efstratiou, N., Karetsou A., Banou E., and Margomenou D.: The Neolithic settlement of Knossos: new light on an old picture, in: Knossos: palace, city, state (British School at Athens Studies 12), edited by: Cadogan, G., Hatzaki, E., and Vasilakis, E., London, British School at Athens, 43-49, 2004.

Efstratiou, N., Biagi, P., Elefanti, P., Karkanas, P., and Ntinou, M.: Prehistoric exploitation of Grevena highland zones: hunters and herders along the Pindus chain of western Macedonia (Greece), World Archaeology, 38, 415-435, 2006.

Fleitmann, D., Mudelsee, M., Burns, S. J., Bradley, R. S., Kramers, J., and Matter, A.: Evidence for a widespread climatic anomaly at around $9.2 \mathrm{ka}$ before present, Paleoceanography, 23, 1-6, 2008.

Fletcher, W. J. and Zielhofer, C.: Fragility of Western Mediterranean landscapes during Holocene rapid climate changes, Catena, 103, 16-29, 2013.

Fletcher, W. J., Debret, M., and Goñi, M. F. S.: Mid-Holocene emergence of a low-frequency millennial oscillation in western Mediterranean climate: implications for past dynamics of the North Atlantic atmospheric westerlies., The Holocene, 23, 153166,2013

Flohr, P., Fleitmann, D., Matthews, R., Matthews, W., and Black, S.: Evidence of resilience to past climate change in Southwest Asia: Early farming communities and the 9.2 and 8.2 ka events, Quaternary Sci. Rev., ., 136, 23-39, 2016.

Fontugne, M., Kuzucuoğlu, C., Karabıyıkoğlu, M., Hatté, C., and Pastre, J.-F.: From Pleniglacial to Holocene. A ${ }^{14} \mathrm{C}$ chronostratigraphy of environmental changes in the Konya Plain, Turkey, Quaternary Sci. Rev., 18, 573-592, 1999.

Forenbaher, S. and Miracle, P. T.: The spread of farming in the Eastern Adriatic, Antiquity, 79, 514-528, 2005.

Frisia, S., Borsato, A., Mangini, A., Spötl, C., Madonia, G., and Sauro, U.: Holocene climate variability in Sicily from a discontinuous stalagmite record and the Mesolithic to Neolithic transition, Quaternary Res., 66, 388-400, 2006.

Fuller, D., Bogaard, A., Charles, M., and Filipovic, D.: Macro- and micro- botanical remains from the 2013 and 2014 seasons, in: Çatalh Hoyük 2014 Archive Report, edited by: Haddow, S. D., 118-135, 2014.

Gehlen, B. and Schön, W.: Klima und Kulturwandel-Mögliche Folgen des "6200-Events" in Europa, Klimaveränderung und
Kulturwandel in neolithischen Gesellschaften Mitteleuropas, 6700-2200, 2005.

Gimbutas, M. (Ed.): Neolithic Macedonia as reflected by excavation at Anza, southeast Yugoslavia, University of California, Los Angeles, 1976.

Glais, A., Lopez-Saez, J.-A., Lespez, L., and Davidson, R.: Climate and human-environment relationships on the edge of the Tenaghi-Philippon marsh (Northern Greece) during the Neolithization process, Quaternary Int., 403, 237-250, 2016.

Gomez, B.: The alluvial terraces and fills of the lower Vasilikos valley, in the vicinity of Kalavasos, Cyprus, Transactions of the Institute of British Geographers, 345-359, 1987.

Gómez-Paccard, M., Larrasoaña, J. C., Sancho, C., Muñoz, A., McDonald, E., Rhodes, E. J., and Beamud, E.: Environmental response of a fragile, semiarid landscape (Bardenas Reales Natural Park, NE Spain) to Early Holocene climate variability: A paleo-and environmental-magnetic approach, Catena, 103, 30 43, 2013.

Göktürk, O. M., Fleitmann, D., Badertscher, S., Cheng, H., Edwards, R. L., Leuenberger, M., and Kramers, J.: Climate on the southern Black Sea coast during the Holocene: implications from the Sofular Cave record, Quaternary Sci. Rev., 30, 2433-2445, 2011.

Greig, J. R. A. and Turner, J.: Some pollen diagrams from Greece and their archaeological Significance, J. Archaeol. Sci., 1, 177194, 1974.

Gürel, A. and Lermi, A.: Pleistocene-Holocene fills of the BorEreğli Plain (central Anatolia): recent geo-archaeological contributions, in: Geoarchaeological activities in southern Capadocia, Turkey, edited by: d'Alfonso, L., Balza, M. E., and Mora, C., Univ. Pavia, 55-70, 2010.

Hourani, F.: Rivière et habitat à Khirokitia (Chypre), Étude de l'évolution hydro-géomorphologique du bassin du Maroni et de son impact sur l'installation néolithique pré-céramique au pied du site, Cahier des thèmes transversaux ArScAn, cahier VI 2004/2005, thème 8 - Bâti et Habitat, 2005, 128-134, 2005.

Hourani F.: Khirokitia (Chypre): un village néolithique les pieds dans l'eau, in: L'eau. Enjeux, usages et représentations (Colloques de la Maison René-Ginouvès, 5), edited by: GumierSorbets, A.-M., Nanterre, 159-169, 2008.

Hourani, F.: Late Chalcolithic/Early Bronze I transition settlements in the middle Jordan Valley: investigating alluvial sequences as a chronostratigraphical framework, and cycles as a social organising component. Paléorient, 123-139, 2010.

Hourani, F. and Courty, M. A.: L'évolution morpho-climatique de 10500 à 5500 BP dans la vallée du Jourdain, Paléorient, 95-105, 1997.

Jones, M. D., Roberts, C. N., and Leng, M. J.: Quantifying climatic change through the last glacial-interglacial transition based on Lake Isotope palaeohydrology from central Turkey, Quaternary Res., 67, 463-473, 2007.

Karamitrou-Mentessidi, G., Efstratiou, N., Kozłowski, J. K., Kaczanowska, M., Maniatis, Y., Curci, A., and Valamoti, S. M.: New evidence on the beginning of farming in Greece: the Early Neolithic settlement of Mavropigi in western Macedonia (Greece), Antiquity, 87, p. 336, 2013.

Karkanas, P., Pavlopoulos, K., Kouli, K., Ntinou, M., Tsartsidou, G., Facorellis, Y., and Tsourou, T.: Palaeoenvironments and site formation processes at the Neolithic lakeside settlement of 
Dispilio, Kastoria, Northern Greece, Geoarchaeology, 26, 83117, 2011.

Kashima, K.: Environmental and climatic changes during the last 20000 years at Lake Tuz, central Turkey, Catena, 48, 3-20, 2002.

Kotthoff, U., Pross, J., Müller, U. C., Peyron, O., Schmiedl, G., Schulz, H., and Bordon, A.: Climate dynamics in the borderlands of the Aegean Sea during formation of sapropel S1 deduced from a marine pollen record, Quaternary Sci. Rev., 27, 832-845, 2008.

Kouli, K. and Dermitzakis, M. D.: Natural and cultural landscape of the Neolithic settlement of Dispilio: palynological results, Hell. J. Geosci., 43, 29-39, 2008.

Kozłowski, J. K.: La néolithisation de la zone balkano-danubienne et l'occupation du territoire. Civilisations, Revue internationale d'anthropologie et de sciences humaines, 9-24, 2004.

Krauß, R., Elenski, N., Weninger, B., Clare, L., Çakırlar, C., and Zidarov, P.: Beginnings of the Neolithic in Southeast Europe: the Early Neolithic sequence and absolute dates from DžuljunicaSmărdeš (Bulgaria), Documenta Praehistorica, 41, 51-77, 2014.

Kühn, P.: Micromorphology and Late Glacial/Holocene genesis of Luvisols in Mecklenburg-Vorpommern (NE-Germany), Catena, 54, 537-555, 2003.

Kuzucuoğlu C., Karabıyıkoğlu M., Fontugne M., Pastre J.-F., and Ercan T.: Environmental changes in Holocene Lacustrine Sequences from Karapinar in the Konya Plain (Turkey), in: Third Millennium BC Climate Change and Old World Collapse, edited by: Dalfes, N., Kukla, G., and Weiss, H., NATO ASI Series 1, 49, 451-464, 1997.

Kuzucuoğlu, C., Parish, R., and Karabıyıkoğlu, M.: The dune systems of the Konya Plain (Turkey), Their relation to the environmental changes in Central Anatolia during the late Pleistocene and Holocene, Geomorphology, 23, 257-271, 1998.

Kuzucuoğlu, C., Fontugne, M., Karabiyıkoğlu, M., and Hatté, C.: Evolution de l'environnement dans la plaine de Konya (Turquie) pendant l'Holocène. In: Anatolian Prehistory. At the Crossroads of Two Worlds, edited by: Otte, M., Liège Univ., 605-624, 1999.

Kuzucuoğlu, C.: Geomorphological mapping as an illustration of geomorphological evolution reconstruction: the example of the Çiftlik plain in Cappadocia (Niğde, Turkey), in: Geomorphology of Holocene records in Turkey, edited by: Öner, E., Izmir Univ. Pub., 181, 133-134, 2013.

Kuzucuoğlu, C.: Contextes régionaux du Néolithique en Anatolie: aspects environnementaux et chronologiques, in: La géoarchéologie française au $\mathrm{XXI}^{e}$ siècle/French geoarcheology in the 21 st century, edited by: Carcaud, N. and Arnaud-Fassetta, G., CNRS Press, Paris, 131-146, 2014.

Kuzucuoğlu, C.: The rise and fall of the Hittite State in central Anatolia: how, when, where, did climate intervene?, in: La Cappadoce méridionale de la préhistoire à la période byzantine, 3èmes Rencontres d'archéologie de l'IFEA, edited by: Beyer, D., Henry, O., and Tibet, A., Istanbul 8-9 Nov. 2012, IFEA, Istanbul, 17-41, 2015.

Lawson, I., Frogley, M., Bryant, C., Preece, R., and Tzedakis, P.: The Lateglacial and Holocene environmental history of the Ioannina basin, north-west Greece, Quaternary Sci. Rev., 23, 15991625, 2004.

Le Brun, A., Cluzan, S., Davis, S. J. M., Hansen, J., and Renault-Miskovsky, J.: Le Néolithique précéramique de Chypre, L'Anthropologie, 91, 283-316, 1987.
Le Brun, A. and Daune-Le Brun, O.: Khirokitia (Chypre): la taille et les pulsations de l'établissement néolithique pré-céramique, nouvelles données, Paléorient, 35, 69-78, 2009.

Le Brun, A., Hourani, F., and Daune-Le Brun, O.: Changing with the years: Khirokitia (Cyprus) at the turn of the seventh-sixth millennium BC, in: Times of Change: 6,000 BC in the Near East and Europe, edited by: Biehl, P. F. and Rosenstock, E., Cambridge, Cambridge University Press, in press, 2016.

Lespez, L., Tsirtsoni, Z., Darcque, P., Koukouli-Chryssanthaki, H., Malamidou, D., Treuil, R., Davidson, R., Kourtessi-Philippakis, G., and Oberlin, C.: The lowest levels at Dikili Tash, Northern Greece: a missing link in the Early Neolithic of Europe, Antiquity, 87, 30-45, 2013.

Lespez, L., Tsirtsoni, Z., Lopez Saez, J.-A., Le Drezen Y., and Glais A.: Beyond determinism: For a local approach to nature/society interactions in the southern Balkans at the transition from the $\mathrm{Ne}$ olithic to the Bronze Age, in: French Geoarchaeology, edited by: Arnaud-Fassetta, G. and Carcaud, N., Paris, éditions du CNRS, 139-153, 2014.

Lespez, L., Glais A., Lopez Saez, J.-A., Le Drezen Y., Tsirtsoni, Z., Davidson, R., Birée, L., and Malamidou D., Mid-Holocene rapid environmental changes and human adaptation in Northern Greece, Quaternary Res., 85, 227-244, 2016.

Lespez, L., Tsirtsoni, Z., Darcque, P., Malamidou, D., KoukouliChryssanthaki, H., and Glais, A.: Identifying the earliest Neolithic settlements in the South-Eastern Balkans: methodological considerations based on the recent geoarchaeological investigations at Dikili Tash (Greek Eastern Macedonia), in: Going West? The spread of farming between the Bosporus and the Lower Danube Region, EAA - Themes in Contemporary Archaeology, edited by: Tsirtsoni, Z., Reingruber, A., and Nedelcheva, P., Maney publishing, in presss, 2016.

Lichardus-Itten, M.: Changes through time in the Early $\mathrm{Ne}$ olithic settlement of Kovačevo, Southwest Bulgaria, in: Times of Change, The Turn from the 7th to the 6th Millennium BC in the Near East and Southeast Europe, Proceedings of the Berlin Conference, edited by: Biehl, P. F. and Rosenstock, E., 2426 November, 2011, in press, 2016.

Perlès, C., Quiles, A., and Valladas, H.: Early seventh-millennium AMS dates from domestic seeds in the Initial Neolithic at Franchthi Cave (Argolid, Greece), Antiquity, 87, 1001-1015, 2013.

Tinner, W. and Lotter, A. F.: Central European vegetation response to abrupt climate change at $8.2 \mathrm{ka}$, Geology, 29, 551-554, 2001.

Macphail, R. I., Romans, J. C. C., and Robertson, L.: The application of micromorphology to the understanding of Holocene soil development in the British Isles; with special reference to early cultivation, Soil Micromorphology, Plaisir: AFES, 647656, 1987.

Magny, M.: Holocene climate variability as reflected by midEuropean lake-level fluctuations and its probable impact on prehistoric human settlement, Quaternary Int., 113, 65-79, 2004.

Magny, M., Combourieu-Nebout, N., de Beaulieu, J. L., BoutRoumazeilles, V., Colombaroli, D., Desprat, S., Francke, A., Joannin, S., Ortu, E., Peyron, O., Revel, M., Sadori, L., Siani, G., Sicre, M. A., Samartin, S., Simonneau, A., Tinner, W., Vannière, B., Wagner, B., Zanchetta, G., Anselmetti, F., Brugiapaglia, E., Chapron, E., Debret, M., Desmet, M., Didier, J., Essallami, L., Galop, D., Gilli, A., Haas, J. N., Kallel, N., Millet, L., Stock, 
A., Turon, J. L., and Wirth, S.: North-south palaeohydrological contrasts in the central Mediterranean during the Holocene: tentative synthesis and working hypotheses, Clim. Past, 9, 20432071, doi:10.5194/cp-9-2043-2013, 2013.

Makorgiannis, T. J., Giles, M. B., and Flocas, A. A.: The problem of the extension of the Siberian Anticyclone towards southeast Europe, and its relation to atmospheric circulation anomalies over the Northern Hemisphere, Arch. Meteor. Geophy A, 30, 185196, 1981.

Marciniak, A., Barański, M. Z., Bayliss, A., Czerniak, L., Goslar, T., Southon, J., and Taylor, R. E.: Fragmenting times: Interpreting a Bayesian chronology for the late Neolithic occupation of Çatalhöyük East, Turkey, Antiquity, 89, 154-176, 2015.

Marino, G., Rohling, E. J., Sangiorgi, F., Hayes, A., Casford, J. L., Lotter, A. F., and Brinkhuis, H.: Early and middle Holocene in the Aegean Sea: interplay between high and low latitude climate variability, Quaternary Sci. Rev., 28, 3246-3262, 2009.

Matessi A., Gürel A., Kuzucuoğlu C., and d'Alfonso L.: East of Konya: Settlements, routes and environment in Southern Cappadocia, and the political landscape of South Central Anatolia during the Second Millennium BCE, Byzas, in press, 2016.

Mayewski, P., Rohling, E. E., Stager, J. C., Karlé, W., Maasch, K., Meeker, L. D., Meyerson, E. A., Gasse, F., van Kreveld, S., Holmgren, K., Lee-Thorp, J., Rosqvist, G., Rack, F., Staubwasser, M., Schneider, R., and Steig, E. J.: Holocene climate variability, Quaternary Res., 62, 243-255, 2004.

Migowski, C., Stein, M., Prasad, S., Negendank, J. F. W., and Agnon, A.: Holocene climate variability and cultura evolution in the Near East from the Dead Sea sedimentary record, Quaternary Res., 66, 421-431, 2006.

Mlekuž, D.: The ethnography of the Cyclops: Neolithic pastoralists in the eastern Adriatic, Documenta Praehistorica, 32, 15-51, 2005.

Mlekuž, D., Budja, M., Payton, R., and Bonsall, C.: "Mind the gap": Caves, radiocarbon sequences, and the Mesolithic-Neolithic transition in Europe-lessons from the Mala Triglavca rockshelter site, Geoarchaeology, 23, 398-416, 2008.

Müller, U., Pross, J., Tzedakis, P. C., Gamble, C., Kotthoff, U., Schmiedl, G., Wulf, S., and Christanis, K.: The role of climate in the spread of modern humans into Europe, Quaternary Sci. Rev., 30, 273-279, 2011.

Naruse, T., Kitagawa, H., and Hisashi, M.: Lake level changes and development of alluvial fans in Lake Tuz and the Konya basin during the last 24000 years on the Anatolian plateau, Turkey, Japan Review, 8, 65-84, 1997.

Nesje, A. and Dahl, S. O.: The Greenland 8200 cal. yr BP event detected in loss-on-ignition profiles in Norwegian lacustrine sediment sequences, J. Quaternary Sci., 16, 155-166, 2001.

Nikolova, L.: Toward an evolutionary model of gradual development of social complexity among the Neolithic pottery communities in the Balkans (cultural-chronological and culturalanthropological problems), Museo Civico di Storia Naturale, Trieste, Quadernaro XII, 89-102, 2007.

Özbaşaran, M.: The Neolithic on the Plateau, in: Ancient Anatolia 10,000-323 B.C.E., edited by: Steadman, S. R. and McMahon, G., The Oxford Handbook of Ancient Anatolia, Oxford University Press, 99-124, 2011.
Özdoğan, M.: Amidst Mesopotamia-centric and Euro-centric approaches: the changing role of the Anatolian peninsula between the East and the West, Anatolian Studies, 57, 17-24, 2007.

Özdoğan, M.: Archaeological evidence on the Westward expansion of farming communities from Eastern Anatolia to the Aegean and the Balkans, Curr. Anthropol., 52, 415-430, 2011.

Özdoğan, N., Başgelen, and Kuniholm, P. (Eds.): The Neolithic in Turkey, New Excavations and New Research, vol. 3 and vol.4: Central Turkey, Archaeology and Art Publications, Istanbul, 279 pp., 2012.

Perrin, T.: Caractères et évolution de l'outillage de pierre de Shillourokambos-Secteur 1 (Parekklisha, Chypre), in: Le Néolithique de Chypre, supplément 43 au Bulletin de Correspondance Hellénique, edited by: Guilaine, J. and Le Brun, A., Athènes, 175-185, 2003.

Peyron, O., Goring, S., Dormoy, I., Kotthoff, U., Pross, J., De Beaulieu, J. L., and Magny, M.: Holocene seasonality changes in the central Mediterranean region reconstructed from the pollen sequences of Lake Accesa (Italy) and Tenaghi Philippon (Greece), The Holocene, 21, 131-146, 2011.

Peyron, O., Magny, M., Goring, S., Joannin, S., de Beaulieu, J.L., Brugiapaglia, E., Sadori, L., Garfi, G., Kouli, K., Ioakim, C., and Combourieu-Nebout, N.: Contrasting patterns of climatic changes during the Holocene across the Italian Peninsula reconstructed from pollen data, Clim. Past, 9, 1233-1252, doi:10.5194/cp-9-1233-2013, 2013.

Pross, J., Kotthoff, U., Müller, U. C., Peyron, O., Dormoy, I., Schmiedl, G., and Smith, A. M.: Massive perturbation in terrestrial ecosystems of the Eastern Mediterranean region associated with the 8.2 kyr BP climatic event, Geology, 37, 887-890, 2009.

Rasmussen, S. O., Vinther, B. M., Clausen, H. B., and Andersen, K. $\mathrm{K}$ : Early Holocene climate oscillations recorded in three Greenland ice cores, Quaternary Sci. Rev., 26, 1907-1914, 2007.

Roberts N., Black S., Boyer P. Eastwood W., Griffiths H. I., Lamb H. F., Leng M. J., Parish R., Reed J. M., Twigg D., and Yiğitbaşığlu, H.: Chronology and stratigraphy of Late Quaternary sediments in the Konya Basin, Turkey: Results from the KOPAL Project, Quaternary Sci. Rev., 18, 611-630, 1999.

Roberts, N., Reed, J. M., Leng, M. J., Kuzucuoğlu, C., Fontugne, M., Bertaux, J., and Karabiyikoğlu, M.: The tempo of Holocene climatic change in the eastern Mediterranean region: new highresolution crater-lake sediment data from central Turkey, The Holocene, 11, 721-736, 2001.

Roberts, N., Jones, M. D., Benkaddour, A., Eastwood, W. J., Filippi, M. L., Frogley, M. R., and Stevens, L: Stable isotope records of Late Quaternary climate and hydrology from Mediterranean lakes: the ISOMED synthesis, Quaternary Sci. Rev., 27, 24262441, 2008.

Roberts, N., Eastwood, W. J., Kuzucuoğlu, C., Fiorentino, G., and Caracuta, V.: Climatic, vegetation and cultural change in the eastern Mediterranean during the mid-Holocene environmental transition, The Holocene, 21, 147-162, 2011.

Robinson, S. A., Black, S., Sellwood, B. W., and Valdes, P. J.: A review of palaeoclimates and palaeoenvironments in the Levant and Eastern Mediterranean from 25,000 to 5000 years BP: setting the environmental background for the evolution of human civilisation, Quaternary Sci. Rev., 25, 1517-1541, 2006. 
Rogers, J. C.: North Atlantic storm track variability and its association to the North Atlantic Oscillation and climate variability of northern Europe, J. Clim., 10, 1635-1647, 1997.

Rohling, E., Mayewski, P., Abu-Zied, R., Casford, J., and Hayes, A.: Holocene atmosphere-ocean interactions: records from Greenland and the Aegean Sea, Clim. Dynam., 18, 587-593, 2002.

Rohling, E. J. and Pälike, H.: Centennial-scale climate cooling with a sudden cold event around 8,200 years ago, Nature, 434, 975979, 2005.

Rohling, E. J., Marino, G., and Grant, K. M.: Mediterranean climate and oceanography, and the periodic development of anoxic events (sapropels), Earth-Sci. Rev., 143, 62-97, 2015.

Rossignol-Strick, M.: The Holocene climatic optimum and pollen records of sapropel 1 in the eastern Mediterranean, 90006000 BP, Quaternary Sci. Rev., 18, 515-530, 1999.

Schemmel, F., Niedermeyer, E. M., Schwab, V. F., Gleixner, G., Pross, J., and Mulch, A.: Plant wax $\delta \mathrm{D}$ values record changing Eastern Mediterranean atmospheric circulation patterns during the 8.2 kyr BP climatic event, Quaternary Sci. Rev., 133, 96-107, 2016.

Schuldenrein, J.: Konispol Cave, southern Albania, and correlations with other Aegean caves occupied in the Late Quaternary, Geoarchaeology, 13, 501-526, 1998.

Simmons, A. H.: The Neolithic revolution in the Near East: transforming the human landscape, University of Arizona Press, 2011.

Simmons, A. H. and Mandel, R.: Test Excavations at Akrotiri-Aetokremnos (Site E), an Early Prehistoric Occupation in Cyprus: Preliminary Report, Report of the Department of Antiquities of Cyprus, 15-24, 1988.

Sordinas A.: Radiocarbon dates from Corfu, Greece, Antiquity 41, p. $64,1967$.

Sordinas A.: Investigations of the prehistory of Corfu during 19641966, Balkan Studies, 10, 399-424, 1969.

Sordinas, A.: The "Sidarian": maritime Mesolithic non-geometric microliths in western Greece, British School at Athens Studies, 89-97, 2003.

Staubwasser, M. and Weiss, H.: Holocene climate and cultural evolution in late prehistoric-early historic West Asia, Quaternary Res., 66, 372-387, 2006.

Stiner, M. C., Buitenhuis, H., Duru, G., Kuhn, S. L., Mentzer, S. M., Munro, N. D., and Özbaşaran, M.: A forager-herder tradeoff, from broad-spectrum hunting to sheep management at Aş1klıHöyük, Turkey, P. Natl. Acad. Sci., 111, 8404-8409, 2014.

Teller, J. T., Leverington, D. W., and Mann, J. D.: Freshwater outbursts to the oceans from glacial Lake Agassiz and their role in climate change during the last deglaciation, Quaternary Sci. Rev., 21, 879-887, 2002.

Thiebault, S.: Les paysages végétaux de Chypre au Néolithique: Premières données anthracologiques, in: Le Néolithique de Chypre, Actes du Colloque International 17-19 Mai 2001, 221230, 2003.

Thomas, E. R., Wolff, E. W., Mulvaney, R., Steffensen, J. P., Johnsen, S. J., Arrowsmith, C., White, J. W. C., Vaughn, B., and Popp, T.: The $8.2 \mathrm{ka}$ event from Greenland ice cores, Quaternary Sci. Rev., 26, 70-81, 2007.

Tonkov, S., Bozilova, E., and Possnert, G.: Postglacial vegetation history as recorded from the subalpine Lake Ribno (NW Rila Mts), Bulgaria, Open Life Sciences, 8, 64-77, 2013.
Triantaphyllou, M. V., Antonarakou, A., Kouli, K., Dimiza, M., Kontakiotis, G., Papanikolaou, M. D., and Dermitzakis, M. D.: Late Glacial-Holocene ecostratigraphy of the south-eastern Aegean Sea, based on plankton and pollen assemblages, GeoMar. Lett., 29, 249-267, 2009.

Tzedakis, P. C., Hooghiemstra, H., and Palike, H: The last 1.35 million years at Tenaghi Philippon: revised chronostratigraphy and long-term vegetation trends, Quaternary Sci. Rev., 25, 34163430, 2006.

Valamoti, S. M.: Harvesting the "wild"? Exploring the context of fruit and nut exploitation at Neolithic Dikili Tash, with special reference to wine, Veg. His. Archaeobot., 24, 35-46, 2015.

van der Leeuw, S., Lane, D., and Read, D.: The long-term evolution of social organization. In: Complexity Perspectives in Innovation and Social Change (85-116), Springer Netherlands, 2009.

Van der Plicht, J., Akkermans, P. M. M. G., Nieuwenhuyse, O., Kaneda, A., and Russell, A.: Tell Sabi Abyad, Syria: radiocarbon chronology, cultural change, and the $8.2 \mathrm{ka}$ event, Radiocarbon, 53, 229-243, 2011.

Vannière, B., Power, M. J., Roberts, N., Tinner, W., Carrión, J., Magny, M., and Vescovi, E.: Circum-Mediterranean fire activity and climate changes during the mid-Holocene environmental transition (8500-2500 cal. BP), The Holocene, 21, 53-73, 2011.

Verheyden, S., Nader, F. H., Cheng, H. J., Edwards, L. R., and Swennen, R.: Paleoclimate reconstruction in the Levant region from the geochemistry of a Holocene stalagmite from the Jeita cave, Lebanon. Quaternary Res., 70, 368-381, 2008.

Vigne, J. D., Carrere, I., Briois, F., and Guilaine, J.: The early process of mammal domestication in the Near East, Curr. Anthropol., 52, 255-271, 2011.

Vigne, J. D., Briois, F., Zazzo, A., Willcox, G., Cucchi, T., Thiébault, S., and Moreau, C.: First wave of cultivators spread to Cyprus at least 10,600 y ago, P. Natl. Acad. Sci., 109, 84458449, 2012.

Wanner, H., Beer, J., Buetikofer, J., Crowley, T. J., Cubasch, U., Flueckiger, J., and Kuettel, M.: Mid-to Late Holocene climate change: an overview, Quaternary Sci. Rev., 27, 1791-1828, 2008.

Weninger, B., Alram-Stern, E., Bauer, E., Clare, L., Danzeglocke, U., Jöris, O., and van Andel, T.: Climate forcing due to the 8200 cal yr BP event observed at Early Neolithic sites in the eastern Mediterranean, Quaternary Res., 66, 401-420, 2006.

Weninger, B., Clare, L., Rohling, E., Bar-Yosef, O., Böhner, U., Budja, M., Bundschuh, M., Feurdean, A., Gebel, H.-G., Jöris, O., Linstädter, J., Mayewski, P., Mühlenbruch, T., Reingruber, A., Rollefson, G., Schyle, D., Thissen, L., and Todorova, H: The Impact of Rapid Climate Change on prehistoric societies during the Holocene in the Eastern Mediterranean, Doc. Praehist. XXXVI, 7-59, 2009.

Weninger, B., Clare, L., Gerritsen, F., Horejs, B., Krauss, R., Lindstädter, J., Ozbal, R., and Rohling, E. J.: Neolithisation of the Aegean and Southeast Europe during the 6600-6000 cal. BC period of rapid climate change, Doc. Praehist., 41, 1-31, 2014.

Wick, L., Lemcke, G., and Sturm, M.: Evidence of Lateglacial and Holocene climatic change and human impact in eastern Anatolia: high-resolution pollen, charcoal, isotopic and geochemical records from the laminated sediments of Lake Van, Turkey, The Holocene, 13, 665-675, 2003.

Wijmstra, T. A.: Palynology of the first 30 metres of a $120 \mathrm{~m}$ deep section in northern Greece, Acta Bot. Neerl., 18, 511-527, 1969. 
Willcox, G.: The distribution, natural habitats and availability of wild cereals in relation to their domestication in the Near East: multiple events, multiple centres, Veg. His. Archaeobot., 14, 534-541, 2005.

Willcox, G., Buxo, R., and Herveux, L.: Late Pleistocene and early Holocene climate and the beginnings of cultivation in northern Syria, The Holocene, 19, 151-158, 2009.

Willcox, G. and Stordeur, D.: Large-scale cereal processing before domestication during the tenth millennium cal BC in northern Syria, Antiquity, 86, 99-114, 2012.

Willis, K. J.: The vegetational history of the Balkans, Quaternary Sci. Rev., 13, 769-788, 1994.
Zeder, M. A.: The origins of agriculture in the Near East, Curr. Anthropol., 52, 221-235, 2011.

Zhang, X., Reed, J., Wagner, B., Francke, A., and Levkov, Z.: Lateglacial and Holocene climate and environmental change in the northeastern Mediterranean region: diatom evidence from Lake Dojran (Republic of Macedonia/Greece), Quaternary Sci. Rev., 103, 51-66, 2014.

Zielhofer, C. and Faust, D., Mid-and Late Holocene fluvial chronology of Tunisia, Quaternary Sci. Rev., 27, 580-588, 2008.

Zielhofer, C., Clare, L., Rollefson, G., Wächter, S., Hoffmeister, D., Bareth, G., and Weninger, B.: The decline of the early Neolithic population center of' Ain Ghazal and corresponding earthsurface processes, Jordan Rift Valley, Quaternary Res., 78, 427 441, 2012. 